University of Michigan Law School

University of Michigan Law School Scholarship Repository

Articles

Faculty Scholarship

1987

\title{
Siamese Essays: (I) CTS Corp. v. Dynamics Corp. of America and Dormant Commerce Clause Doctrine; (II) Extraterritorial State Legislation
}

Donald H. Regan

University of Michigan Law School, donregan@umich.edu

Available at: https://repository.law.umich.edu/articles/343

Follow this and additional works at: https://repository.law.umich.edu/articles

Part of the Constitutional Law Commons, Courts Commons, Jurisdiction Commons, State and Local Government Law Commons, and the Supreme Court of the United States Commons

\section{Recommended Citation}

Regan, Donald H. "Siamese Essays: (I) CTS Corp. v. Dynamics Corp. of America and Dormant Commerce Clause Doctrine; (II) Extraterritorial State Legislation." Mich. L. Rev. 85 (1987): 1865-913.

This Essay is brought to you for free and open access by the Faculty Scholarship at University of Michigan Law School Scholarship Repository. It has been accepted for inclusion in Articles by an authorized administrator of University of Michigan Law School Scholarship Repository. For more information, please contact mlaw.repository@umich.edu. 


\title{
ESSAYS
}

\section{SIAMESE ESSAYS: (I) CTS CORP. v.DYNAMICS CORP. OF AMERICA AND DORMANT COMMERCE CLAUSE DOCTRINE; (II) EXTRATERRITORIAL STATE LEGISLATION}

\author{
Donald H. Regan*
}

What follows is two essays, related as Siamese twins. Both essays developed from a single conception. They are distinct, but they remain connected by a shared subtopic. The first essay is about CTS Corp. v. Dynamics Corp. of America ${ }^{1}$ as a contribution to dormant commerce clause doctrine. The second essay is about the constitutional principle that states may not legislate extraterritorially, which I shall refer to as the "extraterritoriality principle." The shared subtopic is the extraterritoriality problem in CTS. (There is an extraterritoriality problem in CTS, even though the Court does not discuss it in those terms.)

I could have separated the essays, but it seemed not worth the trouble and the duplication of some of the discussion that separation would have made necessary. Any reader who wishes can read either essay by itself. But many readers who are interested in one essay will be interested in both. Because these are merely essays, it will do them no harm to go through life permanently joined.

\section{CTS CORP. V. DYNAMICS CORP. OF AMERICA AND DORMANT COMMERCE Clause DOCTRINe}

In $C T S$, the Court upholds an Indiana anti-takeover statute. For our purposes, we need only a very loose summary of the statute. Roughly speaking, the statute provides that when an outsider buys a substantial block of shares in a covered Indiana corporation, the outsider does not necessarily succeed to the voting rights normally associ-

* Professor of Law and Professor of Philosophy, University of Michigan. B.A. 1963, Harvard University; LL.B. 1966, University of Virginia; M.Phil. (Economics) 1968, Oxford University; Ph.D. (Philosophy) 1980, University of Michigan. - Ed. I would like to thank Alex Aleinikoff, Don Langevoort, Marty Redish, Mathias Reimann, Fred Schauer, Joel Seligman, and Peter Westen for helpful comments.

1. 107 S. Ct. 1637 (1987). 
ated with those shares. Whether the outsider gets the voting rights is to be decided by a majority vote of the shareholders of the corporation. This statute purports to do no more than define voting rights of shares in Indiana corporations; but its provisions are triggered by a transfer of shares, and in effect it allows a majority of the shareholders of a covered corporation to stop minority shareholders from transferring significant blocks of voting control to outsiders. It is important that the statute applies only to corporations that are incorporated in Indiana (and only to some of those). In restricting its application to resident corporations, the Indiana statute is significantly narrower than the Illinois anti-takeover statute the Court struck down in Edgar v. MITE Corp. ${ }^{2}$ in 1982.

The Indiana statute was challenged by Dynamics Corporation, which wanted to acquire a substantial block of voting shares in the Indiana corporation CTS. Dynamics claimed the Indiana statute was unconstitutional under the dormant commerce clause. (Dynamics also made an argument based on statutory preemption, which I shall ignore, not because it is obviously mistaken, but because I am interested only in the constitutional issues.)

The Court rejects the dormant commerce clause challenge by a vote of six to three. Justice Powell writes the majority opinion, joined by Rehnquist, Brennan, Marshall, and O'Connor, and joined in part by Scalia. Scalia also writes a concurring opinion. White dissents, joined, with respect to his conclusion and the commerce clause part of his opinion, by Blackmun and Stevens. ${ }^{3}$

\section{A. Anti-Balancing}

The first thing I want to point out about CTS is the absence of any reference to balancing in any of the opinions. According to standard doctrine, balancing is an essential part of dormant commerce clause adjudication. The Court announced a balancing test for dormant commerce clause cases in Pike v. Bruce Church, Inc. ${ }^{4}$ in 1970, and the Court has repeated the Pike test in virtually every dormant commerce

2. 457 U.S. 624 (1982). For a fuller description of the Illinois anti-takeover statute struck down in MITE, see text at notes 105-11 infra.

3. Blackmun and Stevens do not join the part of White's dissent that deals with statutory preemption. For discussion of the preemption issue, see Langevoort, The Supreme Court and the Politics of Corporate Takeovers: A Comment on CTS Corp. v. Dynamics Corp. of America, 101 HARV. L. REV. 96, 110-16 (1987). Because I ignore the preemption issue, and also because I have no definite view on a factual issue concerning the purpose of the Indiana statute, see text at notes 32-37 infra, I am not arguing for or against the actual result in CTS.

4. 397 U.S. 137 (1970). 
clause case since. In my view, the standard doctrine is all wrong. ${ }^{5}$ The Court should not balance, and, despite what it says, it does not balance in what I call "movement-of-goods" cases. 6 Movement-ofgoods cases constitute the central line of dormant commerce clause cases, and include both Pike and CTS. If I am right, the Pike test is a red herring. It was not applied even in Pike itself. ${ }^{7}$

I take some pleasure in observing that in none of the three opinions in CTS is there any favorable mention of Pike. Powell mentions Pike just once, in the course of summarizing the opinion below in the Court of Appeals for the Seventh Circuit. ${ }^{8}$ But Powell displays no sympathy for the reasoning of the Court of Appeals, which he ends up reversing. Scalia, in his concurrence, brings up Pike for the sole purpose of stating that the balancing Pike requires is "ill suited to the judicial function and should be undertaken rarely if at all."9 White, in dissent, makes no mention of Pike at all, even though he would strike the statute down on other commerce clause grounds. ${ }^{10}$

Not only is there no favorable mention of Pike, there is no statement in any of the three opinions of a balancing test of any kind. None of the opinions (not even White's dissent) endorses balancing in any way. Powell, writing for the Court, explicitly disclaims any interest in balancing: "We are not inclined 'to second-guess the empirical judgments of lawmakers concerning the utility of legislation'. . .."11 In a similar vein, Scalia states a proposition that all the opinions tend to, when he writes "a law can be both economic folly and constitutional."12

There are sections of Powell's opinion (III.C and III.D) ${ }^{13}$ in which Powell does not say explicitly what he is about, and in which it might seem that he is balancing (even though his disclaimer of balancing, quoted above, appears in section III.C). Scalia's pointed nonconcur-

5. See Regan, The Supreme Court and State Protectionism: Making Sense of the Dormant Commerce Clause, 84 MicH. L. REv. 1091 (1986).

6. "Movement-of-goods" cases include all dormant commerce clause cases except those involving taxation, or regulation of the instrumentalities of transportation, or the state as market participant. I explain why this seemingly ad hoc definition-by-exclusion produces a significant category, indeed the central category for dormant commerce clause analysis (and why a positive definition of the category is possible but less immediately useful), in Regan, supra note 5, especially at 1098-101, 1189-91.

7. For a full discussion of the opinion in Pike, see Regan, supra note 5, at 1209-20.

8. $107 \mathrm{~S}$. Ct. at 1643.

9. $107 \mathrm{~S}$. Ct. at 1652 (Scalia, J., concurring).

10. $107 \mathrm{~S}$. Ct. at 1653 (White, J., dissenting).

11. 107 S. Ct. at 1651 (quoting Kassel v. Consolidated Freightways Corp., 450 U.S. 662, 679 (1981) (Brennan, J., concurring)).

12. $107 \mathrm{~S}$. Ct. at 1653 (Scalia, J., concurring).

13. $107 \mathrm{~S}$. Ct. at 1649-52. 
rence in these sections of Powell's opinion might even suggest that Scalia thinks Powell is balancing here, and that he wants no part of it. ${ }^{14}$ In fact, I think these sections of Powell's opinion do not involve balancing; they are oblique responses to White's arguments that the Indiana statute has a protectionist purpose and regulates extraterritorially. ${ }^{15}$

If Powell does not balance, neither does White. There might seem to be a suggestion of balancing in White's dissent when he says, "The majority ignores the practical impact of the Chapter in concluding that the Chapter does not violate the Commerce Clause."16 But not every reference to practical impact is an invitation to balance. The point White is making here is that the statute does not just regulate the internal structure of corporations. It regulates the transfer of shares. That point is relevant to White's argument about extraterritoriality, which does not involve balancing, as we shall see below. ${ }^{17}$

In sum, none of the three opinions in CTS endorses the Pike test or balancing, and none of the Justices appears to be balancing sub silentio. ${ }^{18}$

\section{B. Discrimination}

If the Court does not balance, how does it decide the commerce clause issue?

Powell begins his commerce clause analysis by saying, "The principal objects of dormant Commerce Clause scrutiny are statutes that discriminate against interstate commerce."19 Scalia joins this part of

\footnotetext{
14. See 107 S. Ct. at 1652 (Scalia, J., concurring).

15. For White's arguments, see text at notes 32-34 \& 45-50 infra.

16. $107 \mathrm{~S}$. Ct. at 1655 (White, J., dissenting).

17. See text around notes 55-56 infra.

18. There is a particular irony in Powell's treatment of Pike in CTS, which I cannot resist pointing out (motivated, I admit, by an "I told you so" mentality). In Edgar v. MITE Corp., 457 U.S. 624 (1982), there was one brief section of White's opinion, the section on Pike-based balancing, that received five votes and thereby became technically the opinion of the Court. It was Powell who contributed the fifth vote. I have argued, in a previous discussion of MITE, that Powell really wanted to uphold the Illinois statute, and that he voted as he did with the sole object of making the official doctrine of MITE as little restrictive of state power as possible. I argued that in the full circumstances of the case, one should not take MITE as a genuine endorsement of Pike-based balancing. Regan, supra note 5, at 1278-83. The irony I now wish to mention is that in his opinion in CTS, Powell discusses MITE without ever mentioning the Pikcbased theory which his vote made the nominal theory of the Court in MITE. Indeed, he discusses MITE as if there were no opinion of the Court at all. He refers to the "plurality" opinion invalidating the Illinois statute on preemption grounds, and elsewhere to White's "plurality" opinion on extraterritoriality. $107 \mathrm{~S}$. Ct. at 1645,1649 . Needless to say, I think this technically inaccurate account of MITE in Powell's CTS opinion is truer to what really went on in MITE than a technically accurate account would have been.
}

19. $107 \mathrm{~S}$. Ct. at 1648. 
Powell's opinion, and adds his own statement of the point: “As long as a State's corporation law governs only its own corporations and does not discriminate against out-of-state interests, it should survive this Court's scrutiny under the Commerce Clause, whether it promotes shareholder welfare or industrial stagnation." 20

So far so good. This recognition that discrimination is the central issue in dormant commerce clause analysis is as much to be applauded as the rejection of balancing. But there are three respects in which I wish the Court had either gone further or been clearer.

First, I wish the Court had recognized that discrimination is the only genuine dormant commerce clause issue in movement-of-goods cases. ${ }^{21}$ Instead, Powell suggests that there is a further issue, namely, whether the statute "adversely may affect interstate commerce by subjecting activities to inconsistent regulations." 22 Now, I think there is a genuine issue that Powell is pointing to with this language. It is the issue of extraterritoriality. But it is misleading to suggest, as Powell does implicitly, that extraterritoriality is a commerce clause issue; and it could be disastrously misleading to refer to the extraterritoriality issue with the language of "inconsistent regulations" (though there are reasons why it is tempting). I shall come back to extraterritoriality and inconsistent regulations after some further comments on Powell's treatment of discrimination.

Another respect in which Powell's treatment of discrimination is disappointing is that he does not explain what he means by "discrimination." (Nor does Scalia.) We are all familiar by now with the fact that "discrimination" may refer to explicit use of disfavored classifications on the face of a statute, or to disparate effect of a statute, or to a legislative purpose of disadvantaging a particular class. So the question arises, which of these meanings is central for dormant commerce clause analysis?

I have argued elsewhere that what is central for dormant commerce clause analysis is discriminatory purpose. ${ }^{23}$ (Effects and explicitness are of course highly relevant evidence on the question of purpose.) Furthermore, I think Powell's opinion adequately reveals that his approach to discrimination turns on purpose in the end.

Powell points out that the statute does not discriminate on its face between in-state and out-of-state tender offerors. ${ }^{24}$ This is true, and

20. 107 S. Ct. at 1653 (Scalia, J., concurring).

21. See Regan, supra note 5, especially at 1160-67, 1174-82.

22. $107 \mathrm{~S}$. Ct. at $1649 ;$;f. $107 \mathrm{~S}$. Ct. at $1652-53$ (Scalia, J., concurring).

23. Regan, supra note 5 , especially at $1125-37$.

24. $107 \mathrm{~S}$. Ct. at $1648-49$. 
relevant, but no one could possibly think that facial neutrality is dispositive of the issue of discrimination (nor does Powell suggest such a thing). The two real candidates for the ultimately determinative consideration are purpose and effect.

As regards the choice between purpose and effect, Powell makes it clear that discriminatory effect is no more the ultimate issue than explicitness is. Dynamics Corporation (the offeror) argued that the statute would have the effect of cutting off more tender offers from out-ofstate entities than from in-state. Powell says this argument "avails Dynamics little."25 Citing Exxon Corp. v. Maryland, ${ }^{26}$ Minnesota v. Clover Leaf Creamery Co., ${ }^{27}$ and Commonwealth Edison Co. v. Montana, ${ }^{28}$ Powell concludes that: "Because nothing in the Indiana Act imposes a greater burden on out-of-state offerors than it does on similarly situated Indiana offerors, we reject the contention that the Act discriminates against interstate commerce." 29 So, discriminatory effect is not the ultimate issue. All that remains is legislative purpose.

Powell's phrase "similarly situated," though it may seem to have nothing to do with purpose, is actually a further indication of concern with purpose. "Similarly situated" cannot mean "identical in all respects," nor can it mean merely "similarly treated by the explicit terms of the statute." It must mean "similar in relevant respects." (We have all been through this in a hundred contexts.) But what is, here, the criterion of "relevant" respects? It cannot be "relevance to an ideal takeover law," since Powell explicitly disclaims any judicial interest in ideal takeover law, in a passage I have already quoted. ${ }^{30}$ It can only be "relevance in the sincere deliberation of constitutionally motivated Indiana legislators." But that means a statute will count as discriminating between similarly situated in-state offerors and out-ofstate offerors if and only if it contains terms adopted for the impermissible purpose of disadvantaging out-of-state offerors as such. In short, purpose is the crux. ${ }^{31}$

25. 107 S. Ct. at 1649.

26. 437 U.S. 117 (1978).

27. 449 U.S. 456 (1981).

28. 453 U.S. 609 (1981).

29. 107 S. Ct. at 1649.

30. Text at note 11 supra.

31. It is because I believe purpose is the crux of discrimination under the dormant commerce clause that I prefer not to follow the Court (or Justice Stevens, writing for the Court) in applying the word "discriminatory" to unfairly apportioned taxes, Tyler Pipe Indus. v. Washington Dept. of Revenue, 107 S. Ct. 2810, 2820 (1987), or to flat-rate taxes, American Trucking Assns. v. Scheiner, 107 S. Ct. 2829, 2842 (1987). It is clear enough why one is inclined to call malapportioned or flat-rate taxes discriminatory; but even so, since the unconstitutionality of these taxes does not depend on the purpose with which they are adopted, I think it is better not to. 
Taking it as established that Powell is concerned with legislative purpose even though he does not say so explicitly, I have one last criticism of his treatment of the discrimination issue: At least on the face of things, Powell is insufficiently imaginative about what sorts of discriminatory purpose might lie behind the statute.

The only sort of discrimination (that is to say, discriminatory purpose) that Powell discusses is discrimination between in-state and outof-state tender offerors. But there are other relevant possibilities, as White's dissent makes clear. White thinks the statute was motivated at least in part by a desire to preserve jobs for Indiana workers and supply contracts for Indiana firms. White sees the statute as a device for discouraging takeovers that would be followed by removal of corporate operations from Indiana. ${ }^{32}$ A statute so motivated would amount to protectionism, attempting to benefit Indiana employees and suppliers at the expense of out-of-staters who might become employees and suppliers if the corporate operations were moved. White is right that state anti-takeover statutes are likely to be motivated in part by such a purpose, and he is right that such a purpose is constitutionally objectionable. So, White raises a serious issue that Powell simply does not address. ${ }^{33}$

I do not mean to assert that White is right on the ultimate factual issue of just what part this protectionist purpose played in the adoption of the statute. The language that White quotes from the State's brief strongly suggests protectionist purpose, ${ }^{34}$ and it seems extremely likely that protectionist purpose played some role in the adoption of the statute. ${ }^{35}$ But I have argued elsewhere that the relevant question is whether the protectionist purpose contributed substantially to the adoption of the statute. ${ }^{36}$ That is a harder question.

One reason the question of substantial contribution is difficult is

32. $107 \mathrm{~S}$. Ct. at $1655-56$ (White, J., dissenting).

33. Powell's failure to address the issue might conceal a number of different attitudes towards the possible purpose of advantaging local workers and suppliers. Powell may have just overlooked the possibility of such a purpose; or he may think that such a purpose would not be constitutionally objectionable (this is one reading of his concurring opinion in Edgar v. MITE Corp., 457 U.S. 624, 646-47 (1982) (Powell, J., concurring in part)). Alternatively, he may be giving the state the benefit of the doubt on the question (discussed further on in the text) of whether Indiana means to be advantaging Indiana workers and suppliers vis-à-vis non-Indiana workers and suppliers (impermissible) or means instead to be protecting workers and suppliers in general against economic dislocation, where the scope of Indiana's power to protect just happens to be limited to Indiana (permissible). (This is also a possible reading of Powell's opinion in MITE.)

34. 107 S. Ct. at 1655-56 (White, J., dissenting).

35. For a strong argument that the Indiana statute was motivated by protectionist purpose, see Langevoort, supra note 3 , at $106-08$.

36. Regan, supra note 5, at 1148-50. 
this: A purpose to protect Indiana workers and suppliers at the expense of non-Indianans is impermissible, but a statute which was motivated by a general belief that takeovers leading to corporate removals are unacceptably disruptive of established economic relations, and which was limited to Indiana corporations simply because those were the only corporations the Indiana legislature had power to regulate, would be perfectly permissible so far as the dormant commerce clause is concerned. Obviously, a subtle decision may be required about just what the legislature was doing. ${ }^{37}$

The subtlety of the decisions about legislative purpose that motive review may require is often mentioned as a reason for rejecting motive review. For myself, I think that even the subtlest decisions about legislative purpose are more consonant with the judicial role and more suited to judges' capacities than the decisions required by balancing. I shall not repeat what I have said elsewhere on this topic (even then relying mostly on others who had written before me). ${ }^{38}$

I do have one new observation. If we ask what subject matter judges as a class are most knowledgeable about (aside from legal doctrine), it is surely politics. It is not physics, chemistry, biology, engi-

37. For the small number of readers who may be interested in the details and the development of my views on the dormant commerce clause, let me point out that in my prior article I discussed the sort of problem noted here only in connection with the "no-singling-out" principle, as opposed to the anti-protectionism principle. Regan, supra note 5, at 1168-69. (For the benefit of any reader who may not have perfect recall of all my principles, the no-singling-out principle goes beyond the anti-protectionism principle by forbidding discrimination between locals and similarly situated foreigners whether or not the locals and foreigners are economic competitors. Like the anti-protectionism principle, the no-singling-out principle focuses on legislative purpose.) I went so far as to suggest (what I assumed at the time, for no reason except insufficient thought) that this sort of problem did not arise in connection with the anti-protectionism principle. We see now that it does. So, one of my stated reasons for preferring the anti-protectionism principle to the no-singling-out principle, id. at $1173-74$, is considerably weakened. I am still inclined to think this sort of problem is more often troublesome in connection with the nosingling-out principle than the anti-protectionism principle; but I shall not argue the point, since I am also now inclined to just go ahead and endorse the no-singling-out principle anyway.

This comment leads to an even more recondite point. The most tortuous part of my earlier article was the argument that statutes like revenue-tariffs involve protectionist purpose as I defined it. Id. at 1121-23. I have no wish to recant any part of that argument, but I would point out that shifting from the anti-protectionism principle to the no-singling-out principle makes the argument otiose. It is clear without argument that revenue-tariffs violate the no-singling-out principle, by intentionally sparing local producers (whose goods are not levied upon) a burden imposed on foreign producers (whose goods are levied upon). (The reason there is a further question about whether the revenue-tariff violates the anti-protectionism principle is that we can at least imagine that this purpose to treat locals better than similarly situated foreigners who happen to be their competitors is not accompanied by a specific purpose to secure for the locals a competitive advantage.)

38. Regan, supra note 5, at 1143-60. The most helpful other writings developing the case for motive review are Brest, Palmer v. Thompson: An Approach to the Problem of Unconstitutional Legislative Motive, 1971 SuP. CT. REv. 95, and Simon, Racially Prejudiced Governmental Actions: A Motivation Theory of the Constitutional Ban Against Racial Discrimination, 15 SAN DIEGO L. REV. 1041 (1978). 
neering, economics, social psychology, and the countless other disciplines relevant to balancing in some case or other. No, it is politics and the behavior of politicians. In other words, motive review, for all its difficulty, is a form of review for which judges are specially wellequipped.

\section{Extraterritoriality}

It may seem to the reader, especially the reader whose primary interest is in corporations law, that my version of the dormant commerce clause simply cannot be the whole story. I have asserted that in movement-of-goods cases, including CTS, the only issue under the dormant commerce clause is whether the state statute was adopted with a discriminatory purpose. ${ }^{39}$ In other words, so long as the Indiana legislature does not seek to secure an unfair advantage for Indiana residents, it can regulate the affairs of even nationally important corporations in any way it pleases without violating the dormant commerce clause. ${ }^{40}$ Can that be right?

I think it is right, but I can sympathize with the feeling that there must be some other colorable constitutional objection to the Indiana statute besides the claim of protectionist purpose. (Some other constitutional objection, over and above the claim of statutory preemption.) There is another colorable constitutional objection, namely, that the Indiana statute is an attempt to legislate extraterritorially.

In my opinion, extraterritoriality is not a dormant commerce clause problem. That is why I can concede that there is an extraterritoriality issue in CTS and yet claim that the only dormant commerce clause issue is protectionist purpose. But I shall hold off my reasons for thinking extraterritoriality is not a dormant commerce clause issue until the second of these twin essays. ${ }^{41}$ The Court has frequently treated extraterritoriality, when it has arisen in the context of a dormant commerce clause case, as if it were a dormant commerce clause problem. ${ }^{42}$ Although I think this is a mistake, I shall pass over the question of the constitutional grounding of the extraterritoriality principle for the present.

I pass over this question in order to focus on two other important propositions about extraterritoriality, propositions which are in-

39. See text at note 21 supra.

40. This assumes that we are not talking about a case involving transportation or taxation. That is, we are still talking about a movement-of-goods case.

41. See Part II infra.

42. E.g., Brown-Forman Distillers Corp. v. New York State Liquor Auth., 106 S. Ct. 2080 (1986); Edgar v. MITE Corp., 457 U.S. 624 (1982). 
dependent of my view about the grounding of the extraterritoriality principle, and which a discussion of the extraterritoriality aspects of $C T S$ will bring into relief: First, the mere fact that a statute has extraterritorial effects does not raise an extraterritoriality problem. Second, the issue of whether a statute is impermissibly extraterritorial is not an issue that calls for balancing.

I have mentioned previously that none of the opinions in CTS talks about extraterritoriality explicitly. None of the Justices uses any variant of the word "extraterritorial." I should therefore like to emphasize, as indirect support for my claim that the Justices are talking about extraterritoriality in CTS, something I have just alluded to in a different connection, namely, that the Court has discussed extraterritoriality explicitly in two other recent dormant commerce clause cases. ${ }^{43}$ Most significantly, Justice White discussed extraterritoriality explicitly in his opinion in CTS's predecessor, Edgar v. MITE Corp. ${ }^{44}$

In CTS, the extraterritoriality theme is clearest in White's dissent. White begins his commerce clause discussion by observing, "Appellant CTS's stock is traded on the New York Stock Exchange, and people from all over the country buy and sell CTS's shares daily."45 White then proceeds to argue that the Indiana law does not merely regulate "the attributes of shares" 46 in the corporation, but also regulates the transfer of shares. White does not explain why this distinction between regulating attributes and regulating transfer is important. In fact, it would not be important if White were engaged in balancing. It would not matter to a balancing analysis whether the Indiana statute were characterized as regulating the attributes of shares or the transfer of shares, precisely because it is clear that either sort of regulation could have significant out-of-state effects to be balanced. ${ }^{47}$ The distinction is important, however, if the issue is extraterritoriality, because the extraterritoriality principle focuses on the location of the behavior the statute governs directly, and not on the location of the statute's effects. The "attributes of shares" in Indiana corporations might seem to exist in Indiana; but as White has just pointed out, the physical events that normally constitute transfer of these shares occur all over the country, and mostly outside Indiana. So, White's insis-

\footnotetext{
43. See cases cited in note 42 supra.

44. 457 U.S. $624,641-43$ (1982) (opinion of White, J.).

45. 107 S. Ct. at 1655 (White, J., dissenting).

46. 107 S. Ct. at 1655 (White, J., dissenting) (quoting Powell, J., 107 S. Ct. at 1652).

47. For confirmation that the distinction between regulating attributes of shares and regulating transfer of shares does not matter to a balancer, see Coffee, Shareholders Versus Managers: The Strain in the Corporate Web, 85 Mich. L. Rev. 1, 93-103 (1986) (Coffee is a balancer, and rejects what he refers to as the "firm/market" distinction.).
} 
tence on the attribute/transfer distinction means he is thinking about extraterritoriality.

Yet another indication that White is thinking about extraterritoriality is his claim that the Indiana law "directly" inhibits or regulates interstate commerce. ${ }^{48}$ As I have said elsewhere in discussing White's opinion in Edgar v. MITE Corp. (where references to "directness" and explicit references to extraterritoriality are intermingled), ${ }^{49}$ White cannot mean to resurrect the old "direct/indirect" test in all its obscure generality. He must have something more specific in mind, and the obvious conclusion is that what he has in mind is the prohibition on extraterritoriality. 50

Just as White raises an extraterritoriality objection without using the word, so does Powell answer him. I suggested earlier in this essay that Powell's reference to the possibility of "inconsistent regulations" 51 was really a reference to the extraterritoriality issue. The connection between inconsistent regulations and extraterritoriality is simple and direct: if every legally regulable event or state-of-affairs could be unambiguously assigned to a unique territorial jurisdiction, then a prohibition on extraterritorial legislation would make inconsistent regulations (passed by different jurisdictions, which is what Powell is worrying about) impossible. One way to attack inconsistency is by a prohibition on extraterritoriality, and one reason to prohibit extraterritoriality is to avoid inconsistency.

I do not claim that talk of inconsistent regulations must imply a concern with extraterritoriality. I claim only that it may, and that in Powell's opinion it does. (I shall have more to say about the broader range of concerns which might be suggested by the phrase "inconsistent regulations" in the next section of this essay.)

Immediately after the brief section of his opinion which discusses inconsistent regulations, Powell launches into a longer section

48. 107 S. Ct. at 1654,1655 (White, J., dissenting).

49. 457 U.S. at 641-643.

50. See Regan, supra note 5, at $1280-81$. It is worth noting, as a point of historical interest and also because it may contribute to White's willingness to speak the language of direct restraints, that in addition to its aptness for characterizing extraterritorial regulations of commerce, "direct" is also a natural adjective to apply to regulations with protectionist purpose. If there is a protectionist purpose, then the legislature passing the law is trying to inhibit some commerce specifically because of its interstateness. In that sense, the regulation of interstate commerce is "direct." Thinking about these natural uses of "direct" would allow us to make more sense of pre-1937 dormant commerce clause jurisprudence than most people would expect (though not perfect sense, by any means). $C$. Sedler, The Negative Commerce Clause as a Restriction on State Regulation and Taxation: An Analysis in Terms of Constitutional Structure, 31 WAYNE L. REV. 885, 933-40 (1985).

51. 107 S. Ct. at 1649. 
(III.C) $^{52}$ which does not clearly announce its topic. The burden of this section is that Indiana corporations are creatures of Indiana law, that Indiana has a time-hallowed right to regulate the internal affairs of Indiana corporations, and that where Indiana corporations are concerned, Indiana has an interest in protecting even non-Indiana shareholders from unfair business dealing. In sum, Indiana corporations, including their relations with non-Indiana shareholders, are within Indiana's legislative jurisdiction. Since our core notion of the basis of jurisdiction is territorial, this is virtually equivalent to claiming that Indiana corporations and their internal affairs exist in Indiana. ${ }^{53}$

Granting that White and Powell are disagreeing about an extraterritoriality issue, even though they do not say so, who is right about that issue? White is clearly right when he says the Indiana statute regulates not just the structure of corporate control but also transfers of corporate control. $\mathrm{He}$ is also right that the physical events that normally accomplish transfers of control - events in brokers' offices and on stock exchanges - happen not just in Indiana but all around the country. However, the actual transfer of control itself - the extinction of one person's legal rights of control and the emergence of such legal rights in someone else - is not a physical event. Even though computer entries representing a sale of stock are made in New York, we can perfectly well deny that New York is the site of the nonphysical event which is the actual transfer of control.

Of course, if the actual transfer is a nonphysical event, and if that is Powell's reason for denying that it occurs in New York, should he not equally recognize that it does not occur in Indiana? Not necessarily. Powell obviously cannot claim the transfer occurs in Indiana because of any (immediate) physical connection with Indiana. But he might say that the transfer is a legal event, and its primary legal connection, which provides its location, is precisely to the state where the relevant corporation is incorporated. In effect, this is Powell's thoroughly traditionalist claim.

(Let me pause to note that if we accept Powell's traditionalist claim - and I shall suggest presently that I am inclined to accept it, in a slightly spruced up version - then White's attempted distinction between the location of transfers of ownership and the location of the

52. $107 \mathrm{~S}$. Ct. at 1649-52.

53. There may be some ineliminable admixture here of an idea of jurisdiction based not on territory, but on citizenship. (The Indiana corporation is an Indiana "citizen.") I shall have something to say about jurisdiction based on citizenship in Part II. I could have talked consistently about problems of "legislative jurisdiction" instead of about problems of "extraterritoriality"; but such punctilio might have made it less immediately apparent to many readers what 1 was talking about. 
internal affairs of the corporation turns out to be illusory for purposes of the extraterritoriality analysis of CTS. Powell's point is that the legal events which are the transfers of ownership should be thought of as occurring wherever the corporation resides and has its internal affairs. But this does not undercut my earlier claim that White's attention to the distinction between transfers of ownership and internal affairs shows he is thinking in extraterritoriality terms. Even if the distinction does not matter to the correct extraterritoriality analysis of $C T S$, it is possible to think it matters. In fact, there are other contexts where it does make sense to distinguish the location of the transfer from the place of residence of the corporation for purposes of extraterritoriality analysis. ${ }^{54}$ And even in the context of CTS, it is much more plausible to think the distinction between transfers of ownership and internal affairs matters to extraterritoriality analysis than to think it matters to balancing. So, my earlier claim about White's intention stands.)

Returning to Powell's traditionalist claim that transfers of ownership take place where the corporation resides, it must be admitted that this claim rings a little hollow despite its roots in a still vital tradition of corporate regulation by states. In the late twentieth century, the fact of legal incorporation may represent an almost vanishingly attenuated practical connection between a corporation and its parent state. Not just because of their nonphysical nature, but also because of their nationwide ramification, the "internal affairs" of many corporations seem to hover above the map of the United States. They seem not really to belong to any particular spot on that map.

So, extraterritoriality analysis does not seem very satisfactory when applied to the problem of who gets to regulate transfers of control of major corporations. Let me emphasize: Even if extraterritoriality analysis seems inept here, that is in no way inconsistent with my claim that extraterritoriality is what the Justices are worried about, nor does it suggest that the Justices have mishandled the analysis. They are attacking a real problem with the best analytical tools at hand. The tools just happen not to do very well in the precise context.

The reader might wonder whether the Justices could not do better by the extraterritoriality problem if they approached it a little less formalistically. For example, instead of worrying about the location of the nonphysical event which is the transfer of control, why not think about the location of the various physical events which will happen in consequence of transfers of control? That is to say, why not conduct

54. See note 116 infra and accompanying text. 
the extraterritoriality analysis in terms of the statute's extraterritorial effects?

This will not do. It is clear that the Court cannot flatly prohibit all state laws that have extraterritorial effects, or even all state laws that have substantial extraterritorial effects. Such a prohibition would invalidate much too much legislation. If extraterritorial effects are to have any constitutional relevance, the most the Court can possibly say is that extraterritorial effects count against a piece of state legislation. But then the Court must decide how much these effects count against the legislation. That way lies balancing. The existence of extraterritorial effects is not an adequate justification for balancing. 55 What is more, we have seen that no Justice was interested in balancing in CTS. So the Justices could not have done what they wanted to do by a less formalistic approach which looked to extraterritorial effects.

We ought to remember that formalism is not all bad. Some degree of formalism is of the essence of law. And one of the virtues of the extraterritoriality principle, stated in terms of what events a state may regulate, is precisely its formalism. The Court can announce the rule that states may not regulate events occurring outside their boundaries, even though such a rule will give rise to some intractable questions about where certain events occur, questions which perhaps can only be decided by judicial fiat. The Court cannot announce a rule that refers to effects, without either prohibiting much more than it ought to or else committing itself to a balancing inquiry for which it is illequipped. There is much wisdom in Justice Scalia's comment about a similar problem in a dormant commerce clause case involving the compensating-tax problem: "I acknowledge that the distinction between a credit [against a tax] and a straight reduction [of a tax] is a purely formal one, but it seems to me less absurd than what we will be driven to if we abandon it." 56

If we put aside the possibility of looking at extraterritorial effects, there is a different argument Powell might have used to make his traditionalist position on the location of transfers of corporate control somewhat more persuasive. It runs as follows: There is a collectiveaction problem here among the shareholders. In the face of certain tender offers, it may be rational for individual shareholders to tender, given their uncertainty about what others will do, even though a majority of the tendering shareholders, perhaps even all of them, would prefer that none of them tender. Because this is a collective-action

55. See Regan, supra note 5, especially at $1160-67,1174-82$.

56. American Trucking Assns. v. Scheiner, 107 S. Ct. 2829, 2852 (1987) (Scalia, J., dissenting). 
problem, it cannot be adequately dealt with by different states regulating the separate transfers between individual shareholders and the offeror according to the location of the most salient physical elements of those transfers. There is no reason of constitutional principle why this sort of problem should not be dealt with by a state legislature. The Constitution presumes that legislatures - and not just Congress but even state legislatures - act sensibly unless they violate specific constitutional prohibitions. So, if we can figure out some way to give one and only one state the power to attack this collective-action problem (only one, so that we will not have inconsistent regulations), then we ought to do so. There is an obvious way to give one and only one state the power. We can say that all the transfers occur in the state of incorporation. Therefore, that is what we will say, for present constitutional purposes. ${ }^{57}$

This argument has an ineliminable formal content, but it sounds less formalistic than the ipse dixit that transfers of corporate control occur in the state of incorporation. (The argument might even seem to involve a sort of balancing at a high level of generality, regarding not the specific effects of the Indiana statute, but rather the effects of generally allowing states-of-incorporation to regulate transfers of control. I think the appearance of balancing even at this high level is illusory, but I shall not argue the point.) Something like this is the argument that I suspect would have led me, if I were' a Justice, to side with Powell on the extraterritoriality issue.

The problem with this argument, of course, is in the formalistic claim that legislatures are presumed to act sensibly. Certainly the Constitution embodies some such presumption, but maybe all we can really say the Constitution presumes about state legislatures is that they act sensibly when they are regulating intraterritorially. In which case, we are right back where we started, looking for the meaning of "intraterritorially." This is the sort of difficulty formalism leads to. In the end, some hard cases must simply be decided by judicial intuitions concerning the spirit of the Constitution. 58

57. Powell does suggest this sort of argument. See 107 S. Ct. at 1646 \& n.7, 1651.

58. Given the traditionalist nature of my conclusion about the extraterritoriality problem, the reader might wonder why I did not simply cite the traditional conflict-of-laws view that a state has broad authority over the internal affairs of domestic corporations, and have done with it. (Powell cites the Restatement (SECOND) of Conflict of Laws $\$ 304$ (1971) for a specific point along these lines. See $107 \mathrm{~S}$. Ct. at 1649.) The reason, of course, is that the common law of conflict of laws is not constitutional law. (The full faith and credit clause determines only the barest outlines of the law of conflicts.) So, even if the argument I make about the constitutional problem regarding extraterritoriality is one of the arguments that would now be offered in support of the traditional conflicts view, the argument still needs to be made in the constitutional context.

Much the same point explains my ignoring throughout these essays the international law of 
(The reader whose main interest is in CTS and who was planning to ignore the later essay on extraterritoriality might wish to take note that there is a brief discussion in that essay of the extraterritoriality aspects of Edgar v. MITE Corp. ${ }^{59}$ )

\section{Inconsistent Regulations}

I turn now to the matter of "inconsistent regulations." Both Powell, in his majority opinion, and Scalia, in his concurrence, say that a state statute may violate the dormant commerce clause not only by discriminating against interstate commerce, but also by creating a danger that interstate commerce will be subjected to inconsistent regulations. ${ }^{60}$

Properly understood, this assertion of Powell's and Scalia's is correct. In fact, there are a number of different "inconsistent regulations" problems under the dormant commerce clause, as I shall explain in a moment. But there is also a serious danger that talk of inconsistent regulations may be misunderstood. It may be taken to indicate that one particular phenomenon raises a dormant commerce clause problem when in fact it does not raise such a problem at all.

I want to forestall this potentially very troublesome misunderstanding, and to that end I propose to discuss what the reference to inconsistent regulations does not mean before I discuss what it does mean. This may seem backwards. But it is the importance of seeing what "inconsistent regulations" does not mean that justifies the existence of this section of the essay.

Recall Minnesota v. Clover Leaf Creamery Co., ${ }^{61}$ in which milk distributors and others challenged a Minnesota statute that forbade the sale in Minnesota of milk in plastic nonreturnable containers. Now imagine that the opinions in CTS, with their references to the danger of inconsistent regulations, had somehow been already in the United States Reports when Clover Leaf was being litigated. Who can doubt that the milk distributors would have argued, citing CTS, that the Minnesota statute impermissibly burdened interstate commerce by creating a situation in which the distributors were subjected to "inconsistent regulations"? The "inconsistency" the distributors would have pointed to was the difference in milk packaging standards between

extraterritoriality. Once we begin to think seriously about extraterritoriality problems under the Constitution, we may be able to learn something from international law. But international law is not American constitutional law.

59. 457 U.S. 624 (1982); see text at notes 105-19 infra.

60. 107 S. Ct. at 1649 (Powell), 1652-53 (Scalia).

61. 449 U.S. 456 (1981). 
Minnesota, on the one hand, and states that permitted plastic nonreturnable containers, on the other. ${ }^{62}$

Now, it is certainly true that if Minnesota and North Dakota, say, have different standards for milk packaging, that may complicate the life of a distributor who wants to market milk in both states. The distributor could even complain of "inconsistent regulations" on milk packaging without doing violence to ordinary language. Even so, this sort of inconsistency in regulation is not generally speaking a constitutional problem at all. The commercial enterprise that chooses to operate in more than one state must simply be prepared to conform its various local operations to more than one set of laws. The Constitution does not give an enterprise any special privileges just because it happens to operate across state lines. ${ }^{63}$

To argue that the Minnesota statute in Clover Leaf poses a constitutionally significant risk of inconsistent regulation is to claim, in effect, that there is a judicially enforceable constitutional interest in uniformity of commercial regulation. But there is no such interest, in general. The idea that there is a general interest in uniformity is inconsistent with our decision to have separate states with separate legislative competences, including separate competences to regulate commerce. ${ }^{64}$

The result of the actual litigation in Clover Leaf reveals that the Court did not regard mere nonuniformity of commercial regulation as

62. It may occur to the reader that the "inconsistency" could be made even more extreme by supposing that some other state required the plastic nonreturnable containers that Minnesota forbade. This would make no difference in the present context. We know the Court upheld the actual Minnesota law. The argument I shall sketch in the text in support of the Court's holding would cover the more extreme sort of "inconsistency" as well. Also, if we suppose it would have mattered to the Court if some other state required the plastic nonreturnable containers, then should not the parties challenging the Minnesota statute have been able to prevail, even in the absence of any such statute elsewhere, by pointing out that market forces "required" them to use the plastic containers for much of their business in states that permitted such containers?

To anticipate the results of some later arguments in the text: Even the most extreme sort of "inconsistency" does not matter, in a movement-of-goods case, unless the two statutes regulate the same physical transaction. $C$. text following note 66 infra. But if the two statutes regulate the same physical transaction, then one of them (normally) is extraterritorial. And if one of them is extraterritorial, it can be struck down even if there is not the most extreme sort of inconsistency, $c f$. the Arizona/Maine speed limit example in text between notes 141 and 142 infra; indeed, it can be struck down even in the absence of demonstrated inconsistency of any kind. $C f$. the case of the traveling New Mexican in text between notes 95 and 96 infra. So, the difference between mild and extreme inconsistency matters much less than we might assume. Only rarely does it matter at all.

63. The Constitution does protect enterprises against special disadvantage that results just from being organized across state lines; but mere variation in regulation from state to state does not constitute such a disadvantage. See Regan, supra note 5, at 1185-89.

64. See Regan, supra note 5 , at 1177,1187 . Of course, there may sometimes be a derivative interest in uniformity, as in the transportation area, but that is not an interest in uniformity simply as such. See id. at 1177 ; text at notes $67-70$ infra. 
a constitutionally significant problem of "inconsistent regulations." And to cite CTS in support of the contrary conclusion in cases like Clover Leaf would be to misread CTS. We shall see in just a moment that Powell and Scalia are worried about "inconsistent regulations" of quite another sort. Unfortunately, what I have characterized as a misreading of CTS is just the sort of misreading that lawyers (and judges, and professors) come up with by paying too much attention to the words of the Court and too little attention to their sense. My object, and my probably fond hope, is to preempt that sort of misreading in this instance.

Very well, supposing I am right about what Powell and Scalia do not mean by their talk of inconsistent regulations, What do they mean? If we look at the cases Powell cites in his discussion of inconsistent regulations, we see that he cites two cases dealing with extraterritoriality ${ }^{65}$ and three cases dealing with state regulation of the instrumentalities of interstate transportation. ${ }^{66} \mathrm{I}$ have already explained how it is that extraterritoriality is bound up with the issue of inconsistent regulations: one of the reasons we want to prohibit extraterritorial legislation is to prevent an actor from finding herself subject to inconsistent regulations governing one and the same transaction. (Notice that a Minnesota law governing milk sales in Minnesota and a North Dakota law governing milk sales in North Dakota will never govern the same transaction, though they may both affect some milk distributor's packaging behavior in Wisconsin.) It is plainly the extraterritoriality problem in CTS, which we have already discussed, that prompts Powell's "inconsistent regulations" discussion.

What of the transportation cases that Powell cites? These cases and others suggest that the Court worries about inconsistent regulations in the transportation context even when the "inconsistent" laws do not govern the same transaction - that is, even when the laws stand in the same relation to each other as the Minnesota and North Dakota laws on milk packaging. The Illinois mudguard law struck down in Bibb v. Navajo Freight Lines ${ }^{67}$ (not cited by Powell, but a good example for him) applied only to trucks being driven in Illinois. No bit of driving was governed both by the Illinois mudguard law and by the "conflicting" Arkansas mudguard law. The Illinois law was struck down nonetheless.

65. Brown-Forman Distillers Corp. v. New York State Liquor Auth., 106 S. Ct. 2080 (1986); Edgar v. MITE Corp., 457 U.S. 624 (1982).

66. Kassel v. Consolidated Freightways Corp., 450 U.S. 662 (1981); Southern Pac. Co. v. Arizona, 325 U.S. 761 (1945); Cooley v. Board of Wardens, 53 U.S. (12 How.) 299 (1851).

67. 359 U.S. 520 (1959). 
Now, it is not clear that the Court currently engages in the sort of review of "inconsistent regulations" in the transportation area that $B i b b$ represents. $B i b b$ is nearly thirty years old, and two of the three transportation cases Powell cites are older still. The only more recent transportation case cited by Powell is Kassel v. Consolidated Freightways Corp., 68 in which there were a plethora of theories and no majority opinion. Even so, I am prepared to concede for purposes of argument that inconsistent regulations review along the lines of $B i b b$ is alive and well. But if it is alive and well, it is also limited to transportation cases. The reason is this. Inconsistent regulations review along the lines of $B i b b$ requires balancing; there is no other way to decide which of the "inconsistent regulations" to invalidate. Balancing has no place in movement-of-goods cases, ${ }^{69}$ but it may be defensible in transportation cases. Transportation cases, unlike movement-of-goods cases, involve a constitutionally significant interest that arguably will not be adequately protected without judicial balancing. The interest in question is the national interest in an efficient transportation and communications network. The transportation and communications infrastructure is important not just to the economy, but also, and more significantly from a constitutional perspective, to the whole project of political union. ${ }^{70}$

For the sake of completeness, I shall go beyond Powell's citations and mention one more dormant commerce clause problem which might be discussed in the language of inconsistent regulations. State taxes on interstate commercial enterprises must meet a standard of fair apportionment; no state may tax more than its fair share of an enterprise's assets or operations. ${ }^{71}$ The reason for this requirement is to avoid cumulative taxation by different states which in the aggregate subjects the interstate enterprise to heavier taxation than it would bear if it operated in any single state. The Court has referred to this requirement of fair apportionment by saying each state's tax must be "internally consistent" - by which the Court means the tax must be such that if it were applied by every jurisdiction, there would be no excessive taxation of interstate enterprises. ${ }^{72}$ This "internal consistency" is really more a matter of generalizability, or hypothetical interstate consistency, than of "internal" consistency. If we start from the premise, as the Court does, that an enterprise should not be taxed

68. 450 U.S. 662 (1981).

69. See notes 5-7 supra and accompanying text.

70. See Regan, supra note 5, at 1184.

71. See Regan, supra note 5, at 1185-86, and materials cited therein.

72. See Container Corp. of Am. v. Franchise Tax Bd., 463 U.S. 159, 169 (1983). 
on more than one-hundred percent of its assets or operations, then the adoption by any state of an unfairly apportioned tax poses the danger that the complete set of state taxes to which an interstate enterprise is subjected will be "inconsistent" in the sense that taxes are levied on more than one-hundred percent of the appropriate base. In this sense, the problem of unfairly apportioned taxes can be seen as a problem of "inconsistent regulations." 73

So, there are at least three genuine constitutional problems which can reasonably be discussed in terms of avoiding inconsistent regulation by states - two dormant commerce clause problems (in the areas of taxation and transportation) and one pseudo-dormant commerce clause problem (extraterritoriality). We can expect that references to inconsistent regulations will continue to appear in commerce clause cases.

But it is important to understand that not every situation that might be characterized in ordinary language as involving inconsistent regulations gives rise to a commerce clause problem (or to a constitutional problem of any sort). Mere diversity of regulation in a case not involving extraterritoriality or taxation or transportation - Minnesota v. Clover Leaf Creamery Co. ${ }^{74}$ is the example I have used, though innumerable others would do as well - is not a constitutional problem at all. Such diversity is precisely what the Constitution contemplates.

\section{EXTRATERRITORIAL State LegisLation}

My main thesis in this second essay is that we do not understand the extraterritoriality principle (the principle that states may not legislate extraterritorially) nearly as well as we should. On the one hand, we have no acceptable account of the constitutional underpinnings of the principle. In dormant commerce clause cases, courts and commentators write as if the extraterritoriality principle were grounded in

73. By referring to the "internal consistency" language in Container Corp., which is about apportionment, I do not mean to endorse the broad reading of that language suggested by the Court's recent opinions in Tyler Pipe Indus. v. Washington Dept. of Revenue, $107 \mathrm{~S}$. Ct. 2810 (1987), and American Trucking Assns. v. Scheiner, 107 S. Ct. 2829 (1987). The actual results in Tyler Pipe and Scheiner are probably correct. The former can be explained by the fact that the tax under review was facially discriminatory, and the latter can be explained by the fact that it involved flat-rate taxes.

Tyler Pipe demonstrates, incidentally, that even a concept like "facially discriminatory," which is designed to establish a bright line, will inevitably have some problematic instances at its boundary. Cf. Regan, supra note 5, at 1229-30 (where I find it necessary to argue that the ordinance under review in Dean Milk Co. v. City of Madison, 340 U.S. 349 (1951), should count as an explicit embargo).

74. 449 U.S. 456 (1981). 
the commerce clause. ${ }^{75}$ In conflicts cases, courts assign the extraterritoriality principle to the due process clause or the full faith and credit clause indifferently, and commentators argue about which is the better view. ${ }^{76}$ And so on. (The truth, I shall argue presently, is that the extraterritoriality principle is not to be located in any particular clause. It is one of those foundational principles of our federalism which we infer from the structure of the Constitution as a whole.) On the other hand, with regard to the content of the extraterritoriality principle, we hardly know how to begin thinking about what the principle entails in any but the easiest cases. (As we shall see, the hard cases may range from retrospective liquor price affirmation laws to attempts by states to apply their ordinary criminal laws to the extraterritorial activity of their own citizens.) Let me emphasize that I shall not offer a general theory of the extraterritoriality principle. I shall be pleased if I spur someone else to do that.

There is one area of our jurisprudence in which extraterritoriality is regularly adverted to, namely conflict of laws. I ought therefore to explain why I shall virtually ignore the conflicts literature. The main reason is that the cases I am interested in are quite unlike the standard fare of conflicts analysis. (CTS and the closely related Edgar v. MITE Corp. ${ }^{77}$ are, of all the cases and hypotheticals I discuss, the ones most nearly resembling traditional conflicts cases.)

How are my cases different from standard conflicts cases? The conflicts scholar would say that my cases are special because I am interested in the extraterritorial application of criminal and regulatory statutes. Such statutes are excluded from the purview of traditional conflicts thinking by the doctrine that one sovereign will not enforce the penal laws of another sovereign ${ }^{78}$ and by the assumption that regulatory laws are not intended by the enacting legislatures to have extraterritorial application. ${ }^{79}$

I am not fully satisfied by this characterization of what distinguishes my inquiry. (I shall offer no characterization of my own, because I do not think I understand extraterritoriality problems well

75. See, e.g., Brown-Forman Distillers Corp. v. New York State Liquor Auth., $106 \mathrm{~S}$. Ct. 2080 (1986), and Edgar v. MITE Corp., 457 U.S. 624 (1982), both discussed in the text below.

76. See Martin, Constitutional Limitations on Choice of Law, 61 CoRNElL L. REv. 185 (1976).

77. 457 U.S. 624 (1982).

78. See, e.g., Huntington v. Attrill, 146 U.S. 657 (1892).

79. Cf. Brilmayer, Interest Analysis and the Myth of Legislative Intent, 78 MiCH. L. REv. 392 (1980). (I cite Brilmayer here as authority for a proposition about traditional conflicts thinking. I do not mean to suggest that she is a traditionalist herself. See note 80 infra and accompanying text.) 
enough to say whether the cases I consider constitute a distinct category, although I admit they do seem distinctive in some respect.) I doubt that we can draw as clear a line between penal or regulatory laws and other laws as the traditional conflicts scholar assumes. And I want to hold open the possibility that thinking about my problems might actually improve our thinking about standard conflicts problems. Insofar as I know anything about conflicts (and I do not know much), my sympathies are with the revisionist trend toward reintroducing territoriality as a basic element in conflicts thinking..$^{80}$ This leads me to suspect that conflicts might benefit from more attention to the relatively "pure" extraterritoriality problems I discuss.

In any event, even if conflicts scholars are right to ignore the problems penal and regulatory statutes present, that does not mean there are no problems. It is true that legislatures do not for the most part intend their penal or regulatory statutes to have extraterritorial effect - partly because it is so clear that the baldest forms of extraterritorial legislation are forbidden by our Constitution. But sometimes states do direct their courts or agencies to apply their own penal or regulatory laws in ways that hover around the borderline of the prohibition on extraterritoriality. Such cases cannot be dealt with by appealing to the principle that one sovereign will not enforce the penal law of another. Nor can they be dealt with by appealing to the assumption that no extraterritoriality is intended. We know what is intended; the question is whether it counts as prohibited extraterritoriality.

If the conflicts literature is unhelpful, the literature on extraterritorial application of criminal laws is equally unhelpful, for an opposite reason. The conflicts literature ignores crimes, and the criminal literature ignores conflicts. The criminal literature rings endless changes on the theme of a course of criminal conduct that unfolds in a succession of jurisdictions; but it tends to assume that the defendant's conduct is reprobated by all jurisdictions concerned, and that the only question is who gets to prosecute and punish him. On these assumptions, it is easy to argue in favor of broad extraterritorial jurisdiction - too easy, for our present purposes. ${ }^{81}$

80. E.g., Brilmayer, supra note 79; Brilmayer, Legitimate Interests in Multistate Problems: As Between State and Federal Law, 79 MICH. L. REv. 1315 (1981); Ely, Choice of Law and the State's Interest in Protecting Its Own, 23 WM. \& MARY L. REV. 173 (1981); Martin, supra note 76.

81. See, e.g., Berge, Criminal Jurisdiction and the Territorial Principle, 30 MICH. L. REv. 238 (1931); Blakesley, A Conceptual Framework for Extradition and Jurisdiction Over Extraterritorial Crimes, 1984 UTAH L. REv. 685; George, Extraterritorial Application of Penal Legislation, 64 Mich. L. REv. 609 (1966); Rotenberg, Extraterritorial Legislative Jurisdiction and the State Criminal Law, 38 Texas L. Rev. 763 (1960). 
With these preliminaries completed, I shall proceed in two stages. First, I shall explain why the extraterritoriality principle should not be regarded as grounded in any particular clause of the Constitution, why it should be regarded as an inference from the structure of our system as a whole. Then I shall discuss some specific extraterritoriality problems, actual and hypothetical - not with an eye to presenting a general theory, but in the hopes of encouraging someone else to try to develop one.

It was commerce clause cases that brought the extraterritoriality principle to my attention, so I shall start by showing that extraterritoriality is not in essence a commerce clause problem. Consider the case of Bonaparte v. Tax Court, 82 which contains an unusually forthright statement of the extraterritoriality principle. Mrs. Patterson, a resident of Baltimore, owned debt securities issued by various cities and states outside Maryland. These securities were exempt from taxation in the issuing states. Mrs. Patterson claimed that by virtue of the full faith and credit clause the securities were also exempt from taxation by Maryland.

A unanimous Supreme Court rejected Mrs. Patterson's claim in an opinion that took just over a page. The reasoning is summed up in a single sentence: "No State can legislate except with reference to its own jurisdiction." 83 Specifically, New York and Pennsylvania and Ohio cannot exempt things from taxation in Maryland. It was not clear that New York and Pennsylvania and Ohio had even tried to exempt their securities from taxation in Maryland (though presumably they would have wanted to if they thought they could); but the Court was quite explicit that they could not do so. ${ }^{84}$ The sentence quoted above does not refer in terms to territory or to extraterritoriality; but the Court's ensuing discussion is all about the situs of the debts and their movability. In short, territoriality is presupposed as the relevant criterion of legislative jurisdiction. The reason New York and the other states cannot exempt their debts from taxation in Maryland is that the debts have taken up residence in Maryland with their owner, Mrs. Patterson.

The Court in Bonaparte cites no constitutional provision in support of its claim that states cannot legislate extraterritorially. And quite properly not, since the extraterritoriality principle is not to be localized in any single clause. In particular, it is clear that the extra-
82. 104 U.S. 592 (1881).
83. 104 U.S. at 594.
84. 104 U.S. at 595. 
territoriality principle as it appears in Bonaparte is not based on the commerce clause. It is not thinking about commerce that makes it seem obvious to the Court (and to the Court's audience) that New York cannot exempt its securities, in the possession of a Maryland resident, from taxation by Maryland.

Reflection on Bonaparte ought to be enough (if pure reffection is not) to establish that the extraterritoriality principle does not flow from the dormant commerce clause. But Bonaparte, with its direct clash of great sovereign powers of borrowing and taxing, may seem too peculiar a case to rely on entirely. So let me discuss a quite different example.

In the present state of constitutional doctrine, states are free to prohibit homosexual sodomy or not, as they see fit. ${ }^{85}$ Georgia forbids it; $; 6$ Illinois does not. Now, imagine that Georgia adopts a law expressly forbidding acts of homosexual sodomy committed by any person anywhere in the United States. An Illinois citizen, traveling in Georgia, is arrested and prosecuted by Georgia authorities for a recent act of homosexual sodomy that occurred in Illinois. The Illinois traveler objects that Georgia cannot do this. And of course, he is right. The Georgia law is a classic example of extraterritorial legislation, and it is forbidden by the Constitution. ${ }^{87}$

The unconstitutionality of the Georgia law has nothing to do with the commerce clause. No commerce is involved. Someone might suggest that the law interferes with a commerce-clause-based right to travel. But the right to travel, commerce-clause-based or otherwise, is not the real issue. Georgia has every right to arrest and prosecute even travelers for crimes within Georgia's legislative competence to prohibit. What is important here is not that the Illinoisan is traveling, but that the act for which he is prosecuted was committed in Illinois.

(Actually, it may be relevant indirectly that the Illinoisan is a traveler, for the following reason. The opposite of a traveler is a resident,

85. See Bowers v. Hardwick, 106 S. Ct. 2841 (1986). I wish I could think of another example besides antisodomy legislation that suited my analytical purposes as well. Although I think Bowers v. Hardwick is at least arguably defensible as a matter of constitutional law, I do not think antisodomy statutes are even arguably defensible as a matter of legislative policy; and I dislike even seeming to suggest that they might be.

86. GA. CODE ANN. $§ 16-6-2$ (1984).

87. This example makes it clear, incidentally, that the problem of extraterritoriality is not simply a problem of states trying to make their laws binding in foreign tribunals. Nobody could entertain this view about extraterritoriality if she actually thought about it, but there are comments in Supreme Court opinions that might mislead the unwary. See, e.g., Alaska Packers Assn. v. Industrial Accident Commn., 294 U.S. 532, 540 (1935) (suggesting a California law escapes condemnation as extraterritorial just because California makes no attempt to compel other states to follow it). 
and a resident of Georgia would be a citizen of Georgia, if we ignore the complication of resident aliens. It is not so obvious that Georgia may not regulate the sexual behavior of Georgians in Illinois as it is that Georgia may not regulate the sexual behavior of Illinoisans in Illinois. States may have some power to legislate extraterritorially where the behavior of their own citizens is concerned. ${ }^{88}$ But not, plainly, when they try to legislate for noncitizens.)

The suggestion that Georgia's extraterritorial law interferes with a commerce-clause-based right to travel is an example of a common error in constitutional analysis. Just as "nature abhors a vacuum," so we are taught to abhor constitutional principles without a specific textual grounding. When such a principle is implicated in some case, we therefore rush in with misguided suggestions for a textual grounding inspired by the context of the case at hand. That is why one thinks here of the right to travel. (The textual grounding of the right to travel is itself very uncertain; but this is an instance of ungroundedness we have learned to live with. So, forgetting that the right to travel is ungrounded, we act as if pointing to the right to travel can provide a grounding for the extraterritoriality principle.) We can see further instances of the same specious approach if we consider other suggestions that inevitably spring to mind about how to ground the claim that Georgia cannot prosecute the Illinois traveler.

One very natural idea is that the article IV privileges and immunities clause forbids the Georgia prosecution (and, by extension, that extraterritoriality has something to do with privileges and immunities). But this is a mistake. The essence of a privileges-and-immunities violation is discrimination against out-of-staters. ${ }^{89}$ There is no discrimination here if we assume that Georgia's intention is to prosecute Georgians equally with Illinoisans for sodomy committed in Illinois. There is a question, as I have noted, whether Georgia can so regulate the out-of-state behavior of Georgians. But even if Georgia can and does regulate the behavior of Georgians in Illinois, it cannot regulate the behavior of Illinoisans in Illinois. So discrimination is not the issue.

Another very natural claim is that the Georgia prosecution violates due process (and, by extension, that the extraterritoriality principle is grounded in the due process clause). But this is not right either. We can leave aside as irrelevant to the present discussion substantive due process arguments about privacy, of the sort rejected in Bowers $v$.

88. For further discussion, see text at notes 133-50 infra.

89. See, e.g., Supreme Court of New Hampshire v. Piper, 470 U.S. 274 (1985). 
Hardwick, ${ }^{90}$ and also any concerns about Georgia's trial procedures, which we assume are impeccable. Not so obviously irrelevant is the question of notice of the existence of the extraterritorial Georgia law. But we can add to our hypothetical the stipulation that the Georgia law is widely publicized throughout the country and that it was actually known to our Illinois traveler, not only when he entered Georgia but even when he committed his act of sodomy in Illinois. This assumption of constructive and actual notice does not remove the objection to the Georgia prosecution. It follows that notice is not the issue. ${ }^{91}$

Notice aside, it might seem that extraterritorial legislation violates a due process requirement of "fundamental fairness." This is the best suggestion yet, but to my mind it is still inadequate. Imagine that in 1800 , when some countries permitted the slave trade and some had forbidden it, one of the abolitionist countries announced that it would prosecute acts of slave taking or slave trading committed anywhere in the world, whenever it happened to get its hands on a perpetrator. It is far from clear that this extraterritorial extension of the country's law would violate fundamental fairness, or shock the conscience, or whatever. Of course, our reaction may be influenced by the heinousness of the crime the country is reaching beyond its borders to punish. But the example shows at least that no notion of fundamental fairness is a clear and absolute bar to extraterritorial legislation.

There is more to say. Suppose we eventually concluded that extraterritorial legislation against the slave trade by an abolitionist nation would be inappropriate despite the laudable goal. Even if we came out this way, it would be a doubtful case. In contrast, it is clear that Massachusetts, in 1800, could not have undertaken to punish traveling Virginians for acts of slave trading committed in Virginia. (And I say with confidence that the inference would be the same even without those clauses of the Constitution that disingenuously embody the original compromise among the states on the slavery problem. ${ }^{22}$ ) But if it is clear that Massachusetts could not legislate extraterritorially about slave trading in Virginia, while it is at least doubtful that an indepen-

90. 106 S. Ct. 2841 (1986).

91. Similarly, we can remove any concern about a prosecution in Georgia making it difficult for the Illinois traveler to produce witnesses in his behalf, by stipulating that there are no such witnesses. Incidentally, the reader who thinks I deal too summarily with considerations of notice and ability to mount a defense may be somewhat mollified by my remarks in the text around notes $99-101$ infra.

92. U.S. CoNST. art. I, \& 2, cl. 3 ("three fifths of all other Persons"); art. I, \$ 9, cl. 1 ("Importation of Such Persons"); art. IV, § 2, cl. 3 ("Person held to Service or Labour"); art. V (prohibiting amendment before 1808 of art. I, $\S 9, \mathrm{cl} .1$ ). 
dent nation would be prevented from doing the same by a requirement of fundamental fairness, we can conclude that Massachusetts is constrained by something more than fundamental fairness. Massachusetts is constrained by an extraterritoriality principle which is a principle, not of fundamental fairness, but of our federalism.

In the preceding paragraphs, we have been talking about fundamental fairness to individuals. Someone might suggest, instead, that the extraterritoriality principle is rooted in a due process requirement of fairness to the interests of other sovereignties. This suggestion also is misguided. For one thing, the argument we have just considered, about extraterritorial antislavery legislation, operates quite as strongly against the claim that the extraterritoriality principle is a matter of fairness to other sovereignties as it does against the claim that the principle is a matter of fairness to individuals. We have seen that Massachusetts is clearly constrained in its relations with Virginia in a way that England (say) is not clearly constrained in its relations with the United States. So the extraterritoriality principle as it operates between states of the United States has some content peculiar to American constitutional law. (When I say "peculiar" to American constitutional law, I do not mean "unique" to American constitutional law. Other federal systems no doubt have comparable internal extraterritoriality principles. This merely confirms that the point is not fundamental fairness to other sovereignties in general, but rather the requirements of a very special system of intersovereign relations.)

There is an even more obvious reason for denying that the extraterritoriality principle depends on a due process requirement of fairness to other sovereignties. Both of our due process clauses are about depriving "persons" of "life, liberty or property." It seems clear that what is contemplated, in both the fifth and fourteenth amendments, is protection of natural persons (possibly extended to include non-natural individuals like corporations) and the sort of interests they have, as opposed to sovereigns and the sort of interests they have. There is nothing in the language or history of either due process clause that suggests the slightest relevance to the problem of relations between the states. 93

The only real arguments for locating the extraterritoriality principle in the due process clause are some ill-considered judicial remarks, ${ }^{94}$ compounded by the accordion-folder quality of the due process clause as we now view it, and a desire to locate the extraterri-

93. Cf. Redish, Due Process, Federalism, and Personal Jurisdiction: A Theoretical Evaluation, 75 Nw. U. L. REv. 1112, 1120 (1981).

94. See cases discussed in Martin, supra note 76. 
toriality principle somewhere in particular. But locating the extraterritoriality principle in the due process clause for reasons such as these merely engenders confusion. Better to admit that the principle has no particular textual home.

The last candidate I want to consider as a possible textual grounding for the extraterritoriality principle is the full faith and credit clause. Extraterritoriality is mentioned most frequently in full faith and credit cases involving choice-of-law problems. In those rare choice-of-law cases where the Court holds that the courts of the forum state must apply the law of some other state rather than their own, ${ }^{95}$ it may seem to be the full faith and credit clause that prohibits application of the law of the forum to an out-of-state transaction. And therefore it may seem that the extraterritoriality principle is grounded in the full faith and credit clause. But appearances are misleading. It is true that in this particular sort of case the full faith and credit clause may duplicate the effect of the extraterritoriality principle. Even so, we should not conclude that the extraterritoriality principle is just a matter of full faith and credit.

The structure of the standard private-law conflicts case leads us to conflate two logically distinct questions: "May the forum state apply its own law?" and "Must the forum state apply the law of some other state?" I say these questions are logically distinct, not logically unrelated. In any particular case, a positive answer to the second question obviously entails a negative answer to the first question. If the forum must apply some foreign law, it may not apply its own law. On the other hand, a negative answer to the first question does not entail a positive answer to the second question. It does not follow from the fact that the forum may not apply its own law that it must apply the law of some other state. The situation with regard to criminal and regulatory laws makes this clear. Even if Georgia may not apply its own criminal laws to behavior of Illinoisans in Illinois, it does not follow in the least that Georgia must be prepared to apply Illinois criminal law, prosecuting traveling Illinoisans who come into Georgia's clutches for Illinois behavior that was a crime in Illinois. (Georgia may have an obligation to extradite, if Illinois requests it, but that is a different matter.)

Our hypothetical about Georgia and the traveling Illinois homosexual might seem to suggest that Georgia has an obligation to "apply" Illinois criminal law in a different way - not by prosecuting traveling Illinoisans for crimes against the law of Illinois, but rather by

95. E.g., John Hancock Mut. Life Ins. Co. v. Yates, 299 U.S. 178 (1936). 
refraining from prosecuting traveling Illinoisans for behavior that was legal in Illinois where it was committed. But this misrepresents the nature of the constraint on Georgia. Imagine that the traveler Georgia wants to prosecute is a New Mexican, who has committed sodomy in New Mexico. Now, I do not know whether sodomy is a crime in New Mexico or not. But even without that knowledge, I say with perfect confidence that Georgia cannot prosecute the traveling New Mexican for his New Mexico behavior. If I am right, the reason obviously cannot be that Georgia is required to apply in any way the law of New Mexico, which by hypothesis I do not know.

So, there are two distinct questions, whether a state may apply its own law in a particular case, and whether it must apply some other state's law. The extraterritoriality principle addresses the first question, and the full faith and credit clause the second. It is true that in any case where the full faith and credit clause requires one state to apply the law of another state, it also implicitly forbids application of forum law. So, in some cases, the command of the full faith and credit clause may duplicate the command of the extraterritoriality principle (even as it adds something further to that command). But there are other cases, as we have just seen, where the extraterritoriality principle operates without any help from the full faith and credit clause. That suggests to me that even in cases where the full faith and credit clause is operative and duplicates the operation of the extraterritoriality principle, it is probably worth thinking of both principles as present and effective.

There are further reasons for keeping the extraterritoriality principle separate in our minds from the full faith and credit clause. For one thing, the extraterritoriality principle and the full faith and credit clause (or at least, arguments appealing to the full faith and credit clause) may come into conflict. Even within the range of traditional conflicts cases, we should remember that in addition to cases where the court is constrained to apply foreign law, there are also cases where it is not so constrained. In such a case, the party who wants the foreign law applied will argue that application of foreign law is required by full faith and credit. The party favoring local law may well respond that to insist on the application of foreign law would give that foreign law an inappropriate extraterritorial extension. This is just what happened in Bonaparte v. Tax Court, ${ }^{96}$ discussed above, where the forthright assertion of the extraterritoriality principle was pre-

96. 104 U.S. 592 (1881). 
cisely in rebuttal to a full faith and credit claim. 97

This suggests a deeper point, about legislative jurisdiction. Full faith and credit cases talk a good deal about legislative jurisdiction. But the full faith and credit clause does not set down principles of legislative jurisdiction. Rather, it presupposes them. As Justice Brandeis said: "[F]ull faith and credit is enjoined by the Constitution only in respect to those public acts which are within the legislative jurisdiction of the enacting State."98 In other words, application of the full faith and credit clause depends on a logically prior understanding of states' legislative jurisdiction. As it happens, the extraterritoriality principle is our central principle of state legislative jurisdiction. Therefore the full faith and credit clause presupposes the extraterritoriality principle. It cannot be regarded as the basis of the principle.

To summarize, the full faith and credit clause presupposes the extraterritoriality principle, and represents a different sort of constraint on the states. The extraterritoriality principle forbids a state from acting on its own laws when it should not. (It also forbids a state from attempting to insist that other states act on its laws, when there is no proper ground for such insistence.) The full faith and credit clause imposes a further requirement, that in some cases a state must stand ready to act on the laws or judgments of another state (assuming the other state had jurisdiction to enact the laws or enter the judgments), whether the first state wants to or not.

Let us now look back for a moment. I have argued that the extraterritoriality principle is not to be located in the commerce clause, or the privileges and immunities clause, or (more significantly) in the due process clause or the full faith and credit clause. The argument has proceeded on the basis of cases and hypotheticals chosen to undermine each successive suggestion about the grounding of the extraterritoriality principle. It might seem that this "divide and conquer" approach proves too much. Let us consider a last, conglomerate hypothetical. Suppose that Georgia wants to prosecute an Indiana traveler for sodomy committed in Indiana. Imagine that, as in an earlier hypothetical, the Indianan had actual notice of the Georgia statute and of its intended extraterritorial operation. 99 Imagine also that Indiana forbids sodomy, and further, that Indiana has, by legislative resolution,

97. Cf. Nevada v. Hall, 440 U.S. 410 (1979); Pacific Employers Ins. Co. v. Industrial Accident Commn., 306 U.S. 493 (1939).

98. Bradford Elec. Light Co. v. Clapper, 286 U.S. 145, 156 (1932). Later cases have seriously undermined the precise holding of Bradford, which upheld the full faith and credit claim, but nothing in later cases casts doubt on the proposition quoted in the text.

99. Imagine also that there is no unfairness to the traveler in the form of barriers to his securing witnesses for his defense, or the like. Cf. note 91 supra. 
expressed its willingness that an Indianan who has committed sodomy in Indiana should be prosecuted under an extraterritorial statute by any other state that acquires custody of the Indianan and that is inclined to prosecute. (After all, if the other state is willing to prosecute, it saves extradition and it saves the time of Indiana courts and prosecutors.) To me, it still seems clear that the extraterritoriality principle forbids the Georgia prosecution. (Indeed, the only way to make it plausible that Georgia might be able to prosecute is to try to recharacterize the prosecution as taking place not under extraterritorial Georgia law, but rather under the Indiana law, with the Georgia courts acting as Indiana courts pro hac vice, by permission of the Indiana legislature.) But the reader might well ask, If Georgia cannot undertake this prosecution, why not? Have we not excluded from the case by stipulation all the reasons that might underlie the prohibition on extraterritoriality? I am not certain whether we have or not, but even assuming we have, that does not mean the extraterritoriality principle cannot apply. I have said previously that some degree of formalism is inseparable from law, 100 and one consequence of formalism is that a rule may apply to a particular case even when none of the reasons underlying the rule is present in the case.

What all this suggests is that the extraterritoriality principle may possibly be a sort of formalistic precipitate from a mixture of considerations, many of which are more purely embodied in other specific constitutional prohibitions. But even if this is so, it emphasizes, rather than derogates from, the operational independence of the extraterritoriality principle. And it is perfectly consistent with the claim that we should justify the extraterritoriality principle, not by pointing to any specific clause of the Constitution, but by a structural inference from our system as a whole. Even the grandest structural inference must depend on ideas that have some concrete manifestation in the constitutional text. ${ }^{101}$

So much for argument about the independence of the extraterritoriality principle. In the remainder of this essay, I shall discuss a few

100. Cf. text preceding note 56 supra.

101. Let me just mention two specific provisions of the Constitution which are arguably relevant to extraterritoriality but which I have not discussed because they are too specialized to be plausible candidates as grounds for the extraterritoriality principle in general. (1) The sixth amendment requires that criminal juries be drawn from "the State and district wherein the crime [was] committed." U.S. CONST. amend. VI. The Supreme Court has never held that this requirement is incorporated into the fourteenth amendment. Ironically, if it were incorporated, it could be pointed to as a specific textual grounding for the extraterritoriality principle in criminal cases requiring juries, since one state cannot call jurors from another state. (2) The extradition provision of article IV, $\S 2$, cl. 2, seems to presuppose some sort of territorial limitation when it refers to "the State having Jurisdiction of the Crime." U.S. CoNSr. art. IV, § 2, cl. 2. 
problematic applications of the principle. I have got this far without an explicit statement of the extraterritoriality principle. It will seem to some readers that I must now, finally, offer a statement of the principle, before I consider the hard cases. I am afraid the reader who wants a more revealing statement of the principle must be disappointed, at least within the confines of this essay. Of course I can state the principle: "For the most part, states may not legislate extraterritorially, whatever exactly that means." But the statement merely emphasizes the vagueness of our understanding. The statement begins with "for the most part" because of the possibility that states may be able to legislate extraterritorially where their own citizens are concerned. ${ }^{102}$ And the statement concludes with "whatever exactly that means" because I do not know exactly what it means to say a state may not legislate extraterritorially. That is the problem I want us to give more thought to. With that introduction - dispiriting or inspiring, depending on your temperament - let us move to the applications.

I would begin by discussing CTS Corp. v. Dynamics Corp. of America, ${ }^{103}$ if I had not already discussed it in the twin of this essay. ${ }^{104}$ For the benefit of any reader who may have skipped the first essay, let me summarize the results of the prior discussion. First, both Powell (writing for the Court) and White (dissenting) recognize and discuss an extraterritoriality problem in CTS, even though they never use any variant of the word "extraterritorial" and even though they mistakenly (in my view) treat the extraterritoriality principle as an aspect of the dormant commerce clause. Second, both Powell and White treat the extraterritoriality principle as a formalistic limitation on state power, which focuses on the location of the events the state is directly regulating. They both recognize implicitly that extraterritoriality review is not triggered by the mere fact of extraterritorial effects, and it does not involve balancing. Finally, the issue Powell and White disagree on is whether transfers of corporate control should be regarded as taking place in the state of incorporation, or whether they should be regarded as taking place where the physical events occur that trigger the transfers (in out-of-state brokers' offices, for example). To the extent Powell suggests that the Indiana statute regulates only the "attributes of shares," it might seem he does not get to this problem about the location of transfers of shares. And White criticizes him on that ground. But it is possible to read Powell as arguing implicitly that even transfers of shares should be regarded (in the context of review-

102. See text at notes $133-50$ infra.

103. 107 S. Ct. 1637 (1987).

104. See Part I supra. 
ing state takeover regulation) as occurring in the state of incorporation, so that the difference between regulating the attributes of shares and regulating transfers of shares, on which White insists, is not a difference that matters. Powell concludes that Indiana may regulate attempted takeovers of Indiana corporations. I suggested that on this point I would probably have voted with Powell.

Let us now consider CTS's predecessor, Edgar v. MITE Corp., ${ }^{105}$ in which Justice White talks about extraterritoriality quite explicitly. MITE involved the application of an Illinois anti-takeover statute to an attempted takeover of the Chicago Rivet \& Machine Co.

The Illinois statute invalidated in MITE differed from the Indiana statute upheld in CTS in two salient respects. First, the Illinois statute was much more explicitly a regulation of takeover bids, that is to say, a regulation of a mechanism for transferring control of corporations. There was not even the possibility of arguing that the Illinois statute regulated only the attributes of shares in corporations. Second, the Illinois statute was written in such a way that it could apply to target corporations that were not incorporated in Illinois and that had no Illinois shareholders. Chicago Rivet was in fact an Illinois corporation, and twenty-seven percent $(27 \%)$ of its shareholders lived in Illinois. ${ }^{106}$ But the statute did not condition its application on those facts, and it is unclear, as we shall see, whether the Justices took them into account.

Do these differences between $M I T E$ and CTS make any difference to the proper extraterritoriality analysis of the two cases? I have already suggested, in discussing $C T S$, that the first difference (the fact that the Illinois statute is much more explicitly a regulation of the takeover process) should not matter. I have suggested that in the present context, we should regard transfers of corporate control as taking place where the corporation has its "internal affairs." So, whatever state has legislative jurisdiction over the attributes of shares in the corporation ought also to have legislative jurisdiction over the process of transferring shares and corporate control. ${ }^{107}$ (Notice that to say the difference in explicit focus between the Illinois and Indiana statutes should not matter to the extraterritoriality analysis is not to deny that this difference might have seemed important to some Justice or other.)

The second difference between the Illinois and Indiana statutes (that the former but not the latter could apply to a foreign corporation

105. 457 U.S. 624 (1982).

106. 457 U.S. at 642 (opinion of White, J.).

107. See text at notes 54-58 supra. And notice the cross-reference there to note $116 \mathrm{infra}$. 
with no in-state shareholders) is more interesting. It actually raises two distinct questions. First, is the Illinois statute constitutionally valid as applied to a non-Illinois target corporation with no Illinois shareholders? Second, if the statute is invalid as applied to such a corporation, can the statute nonetheless be validly applied in a case where the target corporation happens to be an Illinois corporation with a substantial number of Illinois shareholders, even though the statute does not limit itself to such cases? This second question can be restated in other terms: When we are engaged in reviewing a statute under the extraterritoriality principle, what is the significance of overbreadth? Can Illinois save the application of a statute that is overbroad as written by pointing out that the corporation in the case at hand is one it might have regulated under a more narrowly drawn statute?

Having raised the issue of overbreadth in extraterritoriality review, I shall make no attempt to settle it. We need a better understanding of extraterritoriality in general before we can deal adequately with an issue like this. I will point out that a similar issue arises in connection with the extraterritoriality aspects of Brown-Forman Distillers Corp. v. New York State Liquor Authority, ${ }^{108}$ which I shall discuss presently. 109 And it is also worth mentioning that White gives some emphasis in his MITE opinion to the fact that the Illinois statute "could be applied to regulate a tender offer which would not affect a single Illinois shareholder." 110 White's opinion suggests that he might have been reviewing the Illinois statute as written, ignoring the actual facts about the place of incorporation and the ownership of Chicago Rivet. To be sure, White's position in CTS makes it clear in retrospect that it did not matter to White's vote in MITE whether he reviewed the statute as written or not. Anyone who thinks the Indiana statute in CTS was impermissibly extraterritorial would think the same about the Illinois statute even if he were prepared to take into account the actual facts about Chicago Rivet's incorporation and ownership. But the question about overbreadth might still have been relevant to other Justices who voted with White on extraterritoriality in MITE. Burger (who of course did not participate in $C T S$ ) and, even more, O'Connor (who participated in CTS and who thought the Indiana statute was not extraterritorial) may have voted against the Illinois statute in $M I T E$ at least in part because they chose to ignore the actual facts about Chicago Rivet, in view of the breadth of the statute as written.

We have one question still undiscussed, of those I have mentioned:

108. 106 S. Ct. 2080 (1986).

109. See in particular text at notes $130-32$ infra.

110. 457 U.S. at 642 (opinion of White, J.). 
Can Illinois regulate takeover bids when the target corporation is not incorporated in Illinois and has no Illinois shareholders? Of course, Illinois would not claim authority to regulate unless the target corporation had some substantial connection with Illinois. The actual statute applied to a target corporation which was not incorporated in Illinois and had no Illinois shareholders only if the target corporation satisfied two other conditions, namely, that it have its principal executive office in Illinois and that it also have at least ten percent (10\%) of its stated capital and paid-in surplus represented in Illinois. So, is this enough to allow Illinois to regulate takeover attempts?

The same formalistic approach to extraterritoriality that leads to upholding the Indiana statute in $C T S$ suggests that the Illinois statute is invalid in the circumstances we have hypothesized. A corporation which is not incorporated in Illinois and has no Illinois shareholders lacks any connection with Illinois so far as its legal identity and ownership are concerned. So Illinois cannot regulate the internal affairs or ownership of the corporation. In particular, Illinois cannot regulate takeover bids aimed at changing the ownership. Of course, Illinois can regulate the corporation's behavior in Illinois. Illinois can apply its zoning regulations and its safety standards to the buildings in which the corporate offices are housed. Illinois can apply its workers' compensation scheme to employees working in the corporate offices. And so on. But that is because the building and the employees are in Illinois, whereas we have decided that the internal affairs of the corporation are not.

Someone might suggest, on behalf of Illinois, that a change of ownership of the corporation could have very serious consequences in Illinois. The corporation, after the takeover, might even shut its Illinois offices entirely. That is true, but we have seen that the extraterritoriality principle is not about the location of the effects of the regulated behavior. It is about the location of the regulated behavior itself. ${ }^{111}$ If it was no objection to the Indiana statute in CTS that it might have bad effects outside Indiana, it is similarly no defense of the Illinois statute in MITE that it might have good effects inside Illinois.

Consider a hypothetical. Imagine that Michigan decides to prohibit cigarette smoking completely. It forbids the importation, sale, possession, or use of cigarettes in Michigan. Now, we know that if Michigan did this, it would immediately be faced with an enormous problem of smuggling and bootleg cigarettes. To deal with this problem, Michigan would have every incentive to prohibit cigarette manu-

111. See text around note 55 supra. 
facture in North Carolina, if it could do so. But it cannot. The fact that cigarette manufacture in North Carolina has bad effects in Michigan (and it will have bad effects even after Michigan has banned cigarettes, because of the inevitable smuggling) does not give Michigan even the shadow of a justification for prohibiting cigarette manufacture in North Carolina. Similarly, once we have decided to regard transactions in ownership of a corporation as taking place in the state of incorporation, it is of no use to Illinois, trying to regulate a takeover of a foreign corporation, to point out that a successful takeover will have bad effects in Illinois.

Lest my position appear too extreme, I should mention that there are cases upholding the right of a state to punish behavior outside the state which is intended to cause within the state the sort of consequences that are universally condemned by the criminal law. ${ }^{112}$ Certainly we must recognize some exception to the extraterritoriality principle for this sort of case. (That is, we must recognize some exception, in effect. Without making any formal exception, we could solve the problem by taking a broad view of the extent to which intended consequences can be regarded as part of the "behavior." We can either extend the jurisdiction out to the behavior, by recognizing an exception to the extraterritoriality principle, or we can extend the behavior into the jurisdiction, by construing the behavior to include at least some intended consequences.) But the example of Michigan attempting to prohibit cigarette manufacture in North Carolina shows that this exception to the extraterritoriality principle must have its limits also. Illinois' extraterritorial anti-takeover statute does not come within the exception even if we hypothesize, in a particular case, that the takeover offeror intends at the time of offering to close the corporate offices in Illinois. There is not the same intimate connection between the takeover and the closing of the offices as there is between, say, shooting across a state line and killing someone in the state. Nor is the office-closing a consequence the criminal law traditionally condemns. (Illinois may, of course, be able to forbid or deter office-closings directly. But that is another matter.)

Before leaving MITE, let me discuss another aspect of White's opinion. In the part of his MITE opinion which is nominally not about extraterritoriality but about balancing under Pike v. Bruce Church, Inc., ${ }^{113}$ White asserts that Illinois "has no legitimate interest in protecting nonresident shareholders." 114 Now, this is plainly a

112. E.g., Strassheim v. Daily, 221 U.S. 280 (1911).

113. 397 U.S. 137 (1970).

114. 457 U.S. at 644. 
claim about territoriality (or, slightly more broadly, a claim about legislative jurisdiction based on a territorial consideration). So, if we take White's claim at face value, it makes it clear that Pike-based balancing presupposes an understanding of the problem of extraterritoriality, just as does the application of the full faith and credit clause. But as it happens, we cannot take White's claim at face value. What White says about Illinois' interest vis-à-vis nonresident shareholders cannot be right, at least not without some qualification.

One possible objection to White's assertion that Illinois has no interest in protecting nonresident shareholders is raised by Powell in his opinion for the Court in CTS. Powell insists, with considerable justification, that in the case of a resident corporation, the state does have an interest (if it chooses to take an interest) in protecting even nonresident shareholders from "unfair business dealing" for which the corporate form might become a "shield." 115

Even if we join White in discounting the significance of corporate residence, and therefore side with him in this precise disagreement with Powell, White's bald assertion that the state has no interest in protecting nonresident shareholders is still too strong. There is no doubt, for example, that Illinois could enforce its ordinary criminal law of fraud against persons conducting their fraudulent practices out of Illinois, even if the victims of the fraud were out-of-staters and the property they were defrauded of was, instead of cash, their interest in some foreign corporation. Illinois has a perfectly legitimate interest in protecting out-of-staters from the consequences of what it regards as improper behavior in Illinois. ${ }^{116}$

So, we cannot say unqualifiedly that Illinois has no interest in protecting foreign shareholders. White's assertion makes sense only on an implicit assumption that the behavior injuring the foreign shareholders is not itself in Illinois. And that is what White is assuming, as the extraterritoriality section of his opinion confirms.

John Coffee has noticed White's assertion that Illinois has no interest in protecting nonresident shareholders, and Coffee has suggested in response that Illinois may be able to justify its law, or at least raise a

115. CTS Corp. v. Dynamics Corp. of Am., 107 S. Ct. 1637, 1651-52 (1987).

116. Cf. Ely, supra note 80 , at 196-99. Notice that this is a case where it makes sense to distinguish between the location of a transaction which brings about a transfer of ownership in the corporation and the location of the corporation itself. ( $C f$. text at note 54 supra.) The reason is that from the point of view of the state regulation in question, namely the ordinary law of fraud, it is irrelevant that the fraudulently procured property takes the form of shares in a corporation. It is only when the transfer of shares is being regulated specifically qua transfer of corporate ownership (as it is by anti-takeover statutes) that we should regard the transfer as taking place wherever the corporation resides. 
balanceable issue about it, by asserting an interest in protecting local employees of the corporation and local communities. ${ }^{117}$ But this is the wrong response. We have just seen that unless White is implicitly assuming the behavior which harms foreign shareholders occurs outside Illinois, the proper response to his claim that Illinois has no interest in protecting the foreign shareholders is outright denial. And if White is assuming that the behavior occurs outside Illinois, then, as we have seen previously, Illinois cannot justify its regulation, or even begin to justify its regulation, just by pointing out that the regulation serves the interests of Illinois residents. ${ }^{118}$

All of this is further evidence for my claim that Pike-based balancing is a mistake. ${ }^{119}$ If we assume Pike-based balancing makes sense and we try to apply it, we cannot resist importing territoriality considerations, as White does. But if we then look closely at the territoriality considerations, we see that they do not actually operate to qualify or disqualify interests for balancing. Rather, they operate more directly to qualify or disqualify certain laws on the basis of the location of the regulated activity.

Let us now look at another dormant commerce clause case, BrownForman Distillers Corp. v. New York State Liquor Authority, ${ }^{120}$ which involves a quite different extraterritoriality problem. Brown-Forman is a fascinating case in many respects. The economic implications of the New York statute and the question whether the statute was motivated by protectionist purpose are more complex than the Court recognizes. But I shall restrict my attention to the extraterritoriality problem, and

117. Coffee, supra note 47 , at $98-99$.

118. See text at notes 111-12 supra. The reader may wonder what I make of White's assertion that "protecting local investors is plainly a legitimate state objective," 457 U.S. at 644, which occurs just before his assertion that a state has no interest in protecting nonresident shareholders. White could be taken as saying here that a state may protect local investors even against the consequences of out-of-state transactions, which is inconsistent with what I have been arguing. But it is far from clear White means to say this. For one thing, White may have stuck in this claim just for the rhetorical effect of the contrast between protecting residents and protecting foreigners. Certainly it is not the state's right to protect residents that is important to White in the present context. So he may just not have thought much about what he was saying. Alternatively, remember that for White the location of a stock transaction for purposes of extraterritoriality analysis is not tied to the location of the corporation (not even in the context of antitakeover regulation). White's dissent in CTS makes that clear. See text at notes $45-47$ supra. So what White may have in mind is that a state may protect local investors against the ill effects of local stock transactions. In sum, I see no strong reason to read White's claim about protecting local investors as saying anything I would disagree with. But if he really does mean that the state can, in general, protect local investors against the consequences of out-of-state transactions, then I think he is just mistaken.

119. See generally Regan, supra note 5.

120. 106 S. Ct. 2080 (1986). 
indeed to a simplified version of that. ${ }^{121}$

As part of its regulation of the liquor industry, New York had a prospectively operating "affirmation law." This law provided that on the twenty-fifth of each month, any distiller who sold to wholesalers in New York was required to file a price schedule for its products, which would be effective for the second succeeding month. In addition, the distiller was required to affirm that it would not sell liquor at a lower price to any wholesaler anywhere else in the country during that future month. Violations of this affirmation were punishable by revocation of the distiller's license to sell liquor in New York, and by forfeiture of a bond posted by the distiller in connection with the license.

The basic question is, Does this affirmation law run afoul of the extraterritoriality principle? The Court held that it did. I am inclined to think the Court was right.

Once a distiller filed a price schedule with the New York Liquor Authority on May 25, say, for the month of July, it effectively became the law of New York that the distiller could not sell at a lower price, in July, to a wholesaler in Texas. Any sale by the distiller at a lower price in Texas in July would be subject to sanction by the New York Liquor Authority. The case seems essentially identical with the case of the Illinois traveler prosecuted under Georgia's extraterritorial sodomy statute. ${ }^{122}$

There is one difference between Brown-Forman and the Georgia sodomy case. In Brown-Forman, the distiller has cooperated in the creation of the New York law that binds him extraterritorially. He filed the price schedule to which he is held. He might retort that he was required to file the schedule as a condition of doing business in New York; but it remains true that he could have prevented the existence of any New York law relevant to his out-of-state conduct by doing no business in New York, whereas the Illinois traveler had no way of preventing the existence of the Georgia sodomy statute. (The Illinois traveler might have avoided prosecution by staying out of Georgia, but that is a different matter.)

Does it matter that the distiller cooperated in creating the legislation complained of? I doubt that it matters, even if we leave completely to one side his objection that he cooperated under duress. Suppose that Jones, a resident of Illinois, swears out an affidavit in a fit

121. I shall ignore the problems generated by the interaction of different states' policies concerning promotional discounts.

122. See text at notes 85-87 supra. 
of bravado undertaking to be bound by all laws of Georgia that Georgia wishes to give extraterritorial effect to. If Jones thereafter commits an act of homosexual sodomy in Illinois, and follows it by traveling to Georgia, can Georgia prosecute him for what he did in Illinois? I hardly think so. Nor would it be enough even if the affidavit was sworn out in Georgia on a previous trip, and if it was in the form of a promise to obey all the extraterritorial laws of Georgia wherever in the country Jones found himself.

If a free undertaking to be bound by extraterritorial legislation, whether by Jones or by a distiller, does not confer extraterritorial jurisdiction, then it seems even clearer that the distiller's actual affirmation, which was to some degree compelled by the New York licensing requirements, should not grant extraterritorial jurisdiction. Of course, New York might argue that instead of compelling the distiller's cooperation by the threat of exclusion from New York, it has rather bought his cooperation by giving him access to New York. So, New York would say, New York is not worse off than Georgia for having compelled the foreigner's submission to extraterritorial jurisdiction; rather, it is better off for having given good consideration for the foreigner's promise, which ought therefore to be binding.

This raises the question whether New York can count its allowing the distiller to do business in New York as consideration for his submission to extraterritorial jurisdiction. Conceivably it can in the very special circumstances of the liquor business; ${ }^{123}$ but surely it cannot in general. At this point the sharp-eyed reader might point out that in order to understand why New York cannot count allowing the distiller to do business in New York as a boon to the distiller, we must look to the principles embodied in the privileges and immunities clause, or the dormant commerce clause. So much I freely admit. But that does not undermine my previous claim for the independent existence of the extraterritoriality principle. In arguing that the extraterritoriality principle was not grounded in privileges and immunities, or in the dormant commerce clause, or elsewhere, I never meant to suggest that all possible extraterritoriality questions could be resolved without any reference whatsoever to other constitutional values. That is a test for independent existence that no constitutional principle could pass.

Assuming the Court was right to invalidate the prospectively operating affirmation law in Brown-Forman, that raises the question, What

123. How far the twenty-first amendment, sometimes said to give the states plenary power over the liquor business, should be interpreted to justify otherwise unconstitutional state legisla. tion is a matter that currently divides the Court. See, e.g., Stevens' dissent in Brown-Forman, 106 S. Ct. at 2090-91. 
about retrospective affirmation laws? What about a law that requires, along with the filing on May 25 of a price schedule for July, an affirmation that no lower price was charged anywhere in the country during the month of April? The Court explicitly declined to answer this question. ${ }^{124}$ (It has upheld retrospective affirmation laws in the past, ${ }^{125}$ but it explicitly declined to say whether it would respect that precedent in the future.)

At the very least, the Court is right to suspect that the difference between prospective and retrospective affirmation may make a difference. For myself, I think retrospective affirmation laws do not violate the extraterritoriality principle. A retrospective affirmation law adopted in New York conditions what can be done in New York in the future on what has been done in Texas in the past, but it says nothing about what can be done in Texas in the future. It simply does not attempt to govern any future extraterritorial behavior, as the prospective affirmation law does. (Nor does it attempt to govern past behavior anywhere. It is not retrospective in that sense.)

Someone might argue that even a retrospective affirmation law in New York can have an effect on future pricing behavior in Texas. That is absolutely true, but in my opinion it is irrelevant. I have explained already that the extraterritoriality principle is a formal principle. It does not look at effects, which would require balancing. ${ }^{126}$ The question is not where the law has effects, but where the behavior is that the law governs. From that point of view, retrospective affirmation laws are quite different from prospective ones.

Notice that all I have said about retrospective affirmation laws is that they do not violate the extraterritoriality principle. That is not to say they are always constitutional. Because of its explicit reference to economic behavior outside the enacting state, any retrospective affirmation law deserves a close look to see whether it is motivated by protectionist purpose. Remember Baldwin v. G.A.F. Seelig, Inc., 127 in which the Court struck down a New York statute forbidding the sale in New York of milk that had been bought from producers in Vermont at less than New York's minimum-price-to-producers. The statute in Baldwin did not involve any affirmation, but it was like the retrospective affirmation law in that it conditioned the legality of certain current behavior in New York on past pricing behavior elsewhere. The statute in Baldwin was struck down, not because it operated ex-

124. $106 \mathrm{~S}$. Ct. at 2087 n.6.

125. Joseph E. Seagram \& Sons, Inc. v. Hostetter, 384 U.S. 35 (1966).

126. See text around note 55 supra.

127. 294 U.S. 511 (1935). 
traterritorially (although some people have read the case that way), ${ }^{128}$ but because of the statute's clear purpose to protect in-state milk producers, coupled with the impossibility of establishing definitively that the statute did no more than neutralize the competitive damage done to in-state producers by the in-state minimum price. ${ }^{129}$

In addition to the issues we have already canvassed, Brown-Forman also presents an issue about whether extraterritoriality review should focus on the statute as written, or should take into account facts specific to the case at hand. The issue takes a somewhat different form in Brown-Forman than it took in Edgar v. MITE Corp. ${ }^{130}$ In MITE, the question was whether to take into account that Chicago Rivet \& Machine Co. was an Illinois corporation with a substantial number of Illinois shareholders. There was no doubt about this fact; the only doubt was about whether to consider it. In Brown-Forman, in contrast, the question is whether to take into account the possibility that the New York and out-of-state liquor authorities might administer their various regulatory schemes in such a way as to prevent the facially extraterritorial New York law from having any actual influence on distillers' out-of-state pricing behavior. One could argue that if the New York law did not actually influence any out-of-state behavior, it should not be thought of as governing extraterritorial behavior at all. The dissenters were prepared to consider this argument. ${ }^{131}$ The majority was not. ${ }^{132}$

One last case, this time hypothetical. Since I have argued that extraterritoriality is not a commerce clause problem, let me point out a potentially serious non-commerce clause extraterritoriality problem that may be in our future. Suppose that Roe v. Wade ${ }^{133}$ is overruled. (I am not predicting that; but there is no shortage of people who think it a real possibility.) Some states would continue to permit abortion essentially on demand; some states would enact very restrictive abortion laws. Now, imagine that an extreme anti-abortion state adopts a

128. Justice Roberts, writing for the Court in Milk Control Bd. v. Eisenberg Farm Prods., 306 U.S. 346 (1939), appears at one point to say the vice of the statute invalidated in Baldwin was that it "regulate[d] the price to be paid for milk in a sister state." 306 U.S. at 353. See also Blasi, Constitutional Limitations on the Power of States to Regulate the Movement of Goods in Interstate Commerce, in 1 CoURTS AND FREE MARKETS: PERSPECTIVES FROM THE UNITED STATES AND EUROPE 174, 188-91 (T. Sandalow \& E. Stein eds. 1982) (treating Baldwin as a case about extraterritoriality, and distinguishing Eisenberg on that ground). For my reading of Eisenberg, see Regan, supra note 5, at 1257-62.

129. See Regan, supra note 5 , at 1245-52.

130. 457 U.S. 624 (1982).

131. $106 \mathrm{~S}$. Ct. at 2089-90 (Stevens, J., dissenting).

132. $106 \mathrm{~S}$. Ct. at 2086-87.

133. 410 U.S. 113 (1973). 
law not only forbidding abortion in the state, but also forbidding its citizens to have abortions out-of-state. (A felt need to protect the fetus might motivate this unusually direct attempt at extraterritoriality.) Can the state do this?

In his opinion for the Court in Bigelow v. Virginia, Justice Blackmun asserts that Virginia cannot prevent Virginia residents from traveling to New York to obtain services that are legal in New York. ${ }^{134}$ This assertion is not entitled to any significant weight. The immediate problem in Bigelow was not an attempt by Virginia to forbid its citizens from traveling to New York to receive abortion referral services. Rather it was an attempt by Virginia to regulate advertising in Virginia of such services. Nor does Blackmun's assertion that Virginia cannot prevent its residents from traveling to New York to use the services appear to be an essential premise in the argument for the Court's holding that the advertising is constitutionally protected. One could construct an argument for that conclusion that took Blackmun's assertion as a premise, but Blackmun's opinion is sufficiently unstructured so that there is no ground for claiming his actual argument depends on such a premise.

Blackmun cites three cases in support of his assertion that Virginia may not prevent its citizens from traveling to New York to use services legal in New York. But none of the three cases is apposite. United States $v$. Guest ${ }^{135}$ stands for the proposition that there is a right of interstate movement which is constitutionally protected against private interference. Shapiro v. Thompson ${ }^{136}$ is about a right of interstate migration, which involves precisely changing one's state citizenship. ${ }^{137}$ Doe v. Bolton ${ }^{138}$ involves the article IV privileges and immunities clause, and establishes that New York (Georgia, in the original) cannot deny nonresidents access to abortion referral services (abortion services, in the original) operating in New York. This is obviously a quite different issue from whether Virginia can deny its own citizens access to services in New York.

Bigelow was one of the Court's early efforts at protecting its holding in Roe v. Wade against subversion by the states. ${ }^{139}$ Such efforts were necessary, and perhaps still are. But the cases decided with this

134. 421 U.S. 809,824 (1975).

135. 383 U.S. 745 (1966).

136. 394 U.S. 618 (1969).

137. For comment on how the right to change one's citizenship interacts with the problem of extraterritorial regulation of citizens, see text at note 142, and note 150 infra.

138. 410 U.S. 179 (1973).

139. See also Doe v. Bolton, 410 U.S. 179 (1973); Planned Parenthood v. Danforth, 428 U.S. 52 (1976); Bellotti v. Baird, 443 U.S. 622 (1979). 
motivation should be treated with caution as sources of general constitutional doctrine.

Of course, it may still be true, despite my dismissal of Bigelow as authority, that a state cannot forbid its citizens to travel to another state for the purpose of using services or engaging in activities that are legal in the destination state. John Hart Ely has asked in a different context:

[I]sn't there something somehow out of accord with at least our "small c constitution" - out of accord in particular with the reasons we as a nation decided to supersede the Articles of Confederation - in adopting what amounts to a system of "personal law" wherein people carry their home states' legal regimes around with them? ${ }^{140}$

I agree with Ely to this extent: I would say that no one can claim to be in touch with our "small c constitution," or the spirit of our federalism, who does not have some intuition that extraterritorial application by a state of its laws is unconstitutional even where the state's own citizens are concerned. But in the end, I think the stronger intuitions run the other way.

We are a single nation, but we are a nation constituted of separate states, with separate legal systems. The Constitution expressly recognizes the reality and significance of state citizenship, both in article IV and in the fourteenth amendment. Why should we not think of a state as having an interest in its citizens which justifies regulation of their conduct wherever they may be? It is worth mentioning that in Skiriotes v. Florida ${ }^{141}$ the Court allowed Florida to apply its criminal law to a Florida citizen outside of Florida's territorial limits. To be sure, the defendant was not within the territory of any other state or country. He was diving for sponges in international waters bordering Florida. Still, allowing criminal prosecution in these circumstances indicates that a state's constitutionally permissible interest in the behavior of its citizens does not stop at its territorial boundaries.

If the state's interest in the behavior of its citizens does not stop at its territorial boundaries, why should it stop just because the citizen is in some other state? Of course, there must be some limits to a state's extraterritorial regulation of its citizens, in deference to the sovereignty of other states. If Arizona has a maximum speed limit on its freeways of sixty-five miles per hour, Maine should not be allowed to impose on Maine citizens driving through Arizona a speed limit of fifty-five miles per hour, even if that is the law of Maine. This regulation by Maine of the extraterritorial behavior of its citizens would in-

140. Ely, supra note 80, at 192.

141. 313 U.S. 69 (1941). 
terfere too directly with Arizona's scheme for the convenience and safety of traffic on its highways. But for myself, I cannot see that Virginia's forbidding citizens of Virginia from having abortions in New York is subject to any comparable objection. I do not deny that New York may want to have its own law apply to traveling Virginians. New York may be eager to provide a place where Virginians can have abortions. Even if this is the case, I would say that New York simply does not have the same sort of constitutional interest in assisting Virginians to avoid the effects of Virginia law that Arizona has in regulating its highways.

There is one definite and important limitation on the power of a state to make its law a "personal law" for its citizens, which they carry around with them wherever they go. A state cannot forbid its citizens from emigrating. The Virginian who does not merely travel to New York, but who uproots herself and moves her residence to New York, acquires a new citizenship in the process, and she leaves her Virginia citizenship behind. Once she has ceased to be a Virginia citizen, Virginia's hold on her is absolutely at an end. And except in very unusual circumstances (for example, if she has committed a crime and is incarcerated in Virginia), ${ }^{142}$ it is entirely up to her whether to sever her connection with Virginia. If she chooses to, Virginia cannot stop her.

But to say that one can always abandon one's state and its laws by changing one's citizenship is not to say that one can take a holiday from the state's laws, while remaining a citizen, by sojourning elsewhere. (In practice, of course, one usually can. People do it all the time, as when they go to Nevada or New Jersey for a fling in the casinos. The question, however, is whether these holidays from local law are a constitutional entitlement, or whether they are enjoyed at the home state's sufferance.) One could even argue that the standing possibility of changing one's state citizenship, for which one does not require the permission either of the state one abandons or of the state one chooses to adopt, undercuts the claim that shorter holidays from the control of one's state's laws are constitutionally guaranteed.

As is so often the case, the same basic facts might also suggest an argument in the other direction. Thus, we might say that the existence of a constitutional right to change one's state citizenship, and the ease with which one can change, suggest that state citizenship is not really important in our constitutional scheme. And the less important is state citizenship, the less plausible it is that states can bind their citi-

142. For another possible exception to the right to emigrate from one's state, see note 150 infra. 
zens outside the territory of the state. For myself, I would not move so quickly from the premise that one has a right to change one's state citizenship to the conclusion that state citizenship is unimportant. The importance of the states to our federal scheme can hardly be denied. If the states matter and citizenship matters (as the Constitution testifies repeatedly), why should not state citizenship matter? We can turn the latest argument against the importance of state citizenship on its head, just as it turned on its head the preceding argument. Unless state citizenship matters, why should it matter so much that there is a right to change one's citizenship? The practical answer, of course, is that the right to change one's citizenship matters in cases like Shapiro v. Thompson, ${ }^{143}$ where the state is trying to deny benefits to new arrivals. But Shapiro unmistakably presupposes that the state can make a range of important benefits available only to citizens. What Shapiro denies is that there can be a waiting period for citizenship. So, the leading case for the right to change one's citizenship actually confirms that state citizenship is important.

A few paragraphs back, I quoted John Hart Ely. In the pages which precede the question I quoted, Ely discusses Austin v. New Hampshire. ${ }^{144} \mathrm{He}$ points out that Austin can be read as authority against the idea that a state's law is a personal law for its citizens. ${ }^{145}$ Austin is an article IV privileges and immunities case, so it is not directly relevant to the question whether a state can apply its law extraterritorially to its own citizens; and Ely himself expresses doubts about whether Austin ought to stand as written. ${ }^{146}$ But Austin is still sufficiently connected to our concerns, in an area where authority is sparse, to make it worth pausing over.

At issue in Austin was the constitutionality of a New Hampshire commuter's income tax, a tax which quite explicitly applied to the New Hampshire-earned income of nonresidents only. The earned income of residents was not taxed. Faced with a challenge to the tax based on the privileges and immunities clause, New Hampshire attempted to defend the tax on the ground that residents were subjected to substantially equal taxation, in different forms. This argument was not supported by the facts. ${ }^{147}$ New Hampshire's more interesting defense was as follows. By its terms, the New Hampshire tax of four percent was reduced, if the commuter's home state taxed income only

\footnotetext{
143. 394 U.S. 618 (1969).

144. 420 U.S. 656 (1975).

145. Ely, supra note 80 , at $186-91$.

146. Id. at $190-91$.

147. See 420 U.S. at 665 \& n. 10 .
} 
at a lower rate, to the rate at which the income would have been taxed if the commuter had earned it at home. Furthermore, the New Hampshire tax did not apply at all unless the commuter's home state gave her a credit for taxes paid to New Hampshire on her New Hampshire income. ${ }^{148}$ So, New Hampshire argued, the commuter could not be subjected to a higher tax by New Hampshire than was deemed appropriate by her home state; and furthermore, it was in the power of her home state to save her from paying any New Hampshire tax at all, by the simple expedient of denying her a tax credit. In sum, any harm to the commuter should be laid at the feet of her home state, not of New Hampshire.

This defense by New Hampshire the Supreme Court also rejected. The Court appears to be saying that how New Hampshire may treat a nonresident does not depend on how the nonresident's home state treats her or what the nonresident's home state is prepared to claim for her vis-à-vis New Hampshire. That is to some degree inconsistent with the idea that the law of the commuter's state is her "personal law."

Now, I am inclined to think that Austin was rightly decided but that its implications are not as broad as they appear. Let me recall a hypothetical which I have used elsewhere for a slightly different purpose. ${ }^{149}$ Suppose that Illinois has a drinking age of twenty-one, and Wisconsin, which shares a border with Illinois, has a drinking age of eighteen. Suppose further that Wisconsin, out of deference to Illinois' policy about drinking by Illinois teenagers, adopts a law forbidding Illinois residents under age twenty-one from buying liquor in Wisconsin. This Wisconsin law discriminates explicitly, subjecting Illinois residents between eighteen and twenty-one to a burden which Wisconsin residents of the same age are spared. But I am strongly inclined to think this Wisconsin law is constitutional.

The difference between the New Hampshire commuter income tax and the Wisconsin law is this. The discrimination in the New Hampshire law was primarily intended to benefit New Hampshire and New Hampshire residents. New Hampshire was trying to swell its tax revenue at the expense of nonresidents. It is possible that New Hampshire was not totally heedless of its constitutional responsibilities; the New Hampshire legislators may really have believed the "substantially equal taxation" argument the Court so easily rejected. But this much is absolutely clear. There is not the slightest reason to think of New

148. 420 U.S. at 666.

149. See Regan, supra note 5, at 1127. 
Hampshire's fundamental motivation in taxing nonresidents as being respect for the policies of their home states that they should be taxed. Even though New Hampshire limited the tax by reference to certain choices by other states, the positive motivation for the tax was solely to benefit New Hampshire. With the Wisconsin law, in contrast, the primary motivation for drawing the distinction between Illinois and Wisconsin eighteen-to-twenty-year-olds is not benefit to Wisconsin or Wisconsin residents. It is respect for Illinois' wishes about the drinking behavior of its underage citizens. (It is possible, of course, that the same Wisconsin law should have been adopted for the purpose of preserving scarce liquor or scarce space in bars for Wisconsin residents. But that is not the case in my hypothetical.)

The upshot seems to be this. A state may not introduce discriminations against nonresidents into its law in order to benefit itself or its residents, and then defend the discrimination which appears in its own law by saying either that the nonresident is treated no worse than she would be at home or that the nonresident is burdened only by virtue of her own state's acquiescence. (That is Austin.) On the other hand, a state may, at least sometimes, introduce into its law discriminations against nonresidents which are designed in the first instance to respect the interests of other states in the behavior, even the extraterritorial behavior, of their citizens. (I leave for some other occasion questions such as how Wisconsin might know whether Illinois cared about extraterritorial drinking by Illinois teenagers, and whether Wisconsin would be required to respect an announcement by the Illinois legislature that Illinois was content to have its eighteen-to-twenty-year-olds drink in Wisconsin, just so long as they did not do it in Illinois.)

Returning to the matter of abortion laws, the tendency of my remarks is that a state may regulate the extraterritorial behavior of its citizens, and therefore that if Roe v. Wade were overruled, states would be free to forbid their citizens from having abortions elsewhere. This is not a conclusion I am pleased with on policy grounds. I hope no state would do this; and if someone could come up with a constitutional argument against extraterritorial legislation in the abortion context specifically, I would be delighted. ${ }^{150}$ We ought to observe,

150. Unfortunately, it seems more likely that a state would have especially broad powers of extraterritorial legislation where abortion is concerned. (I am still assuming that Roe $v$. Wade is out of the way.) The presence of the fetus makes abortion sui generis in almost any context. Even if the state could not generally regulate the extraterritorial behavior of its citizens, it might yet advance a claim to forbid out-of-state travel for the purpose of securing an abortion, on the ground that traveling with such a purpose would amount to removing the fetus, a sort of protocitizen, from the jurisdiction for the purpose of killing it. Indeed, I think the state could argue in good conscience, on the same grounds, that it could prevent a woman even from moving away completely, with the intention of changing her residence and citizenship, for the purpose of hav- 
however, that it is possible to imagine considerably more sympathetic uses of a state power to legislate extraterritorially for its own citizens than any we have yet discussed. For example, suppose that Illinois tried to preserve its drinking age of twenty-one by forbidding underage Illinoisans from drinking in Wisconsin. Aside from difficulties of enforcement, such a law would have much to recommend it, both as an attempt to minimize drunk driving in Illinois by Illinois teenagers returning from out-of-state adventures, and as part of an attempt by the state to oversee its young citizens' developing relationship with a powerful, and omnipresent, drug.

$$
* * *
$$

Let me emphasize in closing that all of my conclusions about particular cases are tentative. My speculations are offered primarily to demonstrate that what we know about extraterritoriality is much less than what we have still to work out.

ing an abortion. This despite the sacrosanctness, in ordinary contexts, of the citizen's right to abandon her state for a new one. See text at note 142 supra. (I say the state could make this argument in good conscience. But I am fairly clear that at this point the state ought not to prevail.)

It occurred to me just as this essay was going to press that Sosna v. Iowa, 419 U.S. 393 (1975), is a case well worth thinking about in connection with issues about state law as "personal law." In Sosna, the Court upheld a one-year residency requirement for securing a local divorce, despite the strong presumption against durational residency requirements which had been established by Shapiro v. Thompson, 394 U.S. 618 (1969), and succeeding cases. One possible explanation of Sosna is that the Court was deferring to what it saw as Iowa's attempt to accommodate the continuing interests of New York (the state Sosna had left) in Sosna's relationships with family members still in New York. Viewed this way, Sosna is some support for my claim that the Wisconsin discrimination against under-age Illinois drinkers would be constitutional. See text at note 149 supra. Sosna also lends indirect support (alas) to my suggestion earlier in this footnote that a state could in good conscience claim a right to forbid its citizens from abandoning their citizenship in order to seek an abortion. After all, Sosna represents a case where one is not entitled to alter one's citizenship status immediately for all purposes just by one's voluntary choice. Sosna upholds a limitation on the newly acquired citizenship imposed by the destination state; but the abandoned state could also find support in Sosna for its attempt to maintain some aspects of its hold on the departing citizen when that is necessary to protect other members of her family (such as the fetus). 